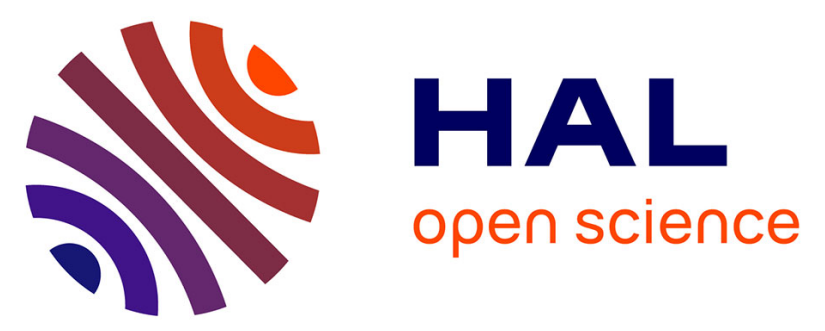

\title{
Baseline seasonal investigation of nutrients and trace metals in surface waters and sediments along the Saigon River basin impacted by the megacity of Ho Chi Minh (Vietnam)
}

Emilie Strady, Vu Bich Hanh Dang, Julien Nemery, Stephane Guedron, Quoc Tuc Dinh, Hervé Denis, Phuoc Dan Nguyen

\section{To cite this version:}

Emilie Strady, Vu Bich Hanh Dang, Julien Nemery, Stephane Guedron, Quoc Tuc Dinh, et al.. Baseline seasonal investigation of nutrients and trace metals in surface waters and sediments along the Saigon River basin impacted by the megacity of Ho Chi Minh (Vietnam). Environmental Science and Pollution Research, 2017, 24 (4), pp.3226-3243. 10.1007/s11356-016-7660-7 . hal-02357360

\author{
HAL Id: hal-02357360 \\ https://hal.science/hal-02357360
}

Submitted on 13 Nov 2019

HAL is a multi-disciplinary open access archive for the deposit and dissemination of scientific research documents, whether they are published or not. The documents may come from teaching and research institutions in France or abroad, or from public or private research centers.
L'archive ouverte pluridisciplinaire HAL, est destinée au dépôt et à la diffusion de documents scientifiques de niveau recherche, publiés ou non, émanant des établissements d'enseignement et de recherche français ou étrangers, des laboratoires publics ou privés. 


\title{
Baseline seasonal investigation of nutrients and trace metals in surface waters and sediments along the Saigon River basin impacted by the megacity of Ho Chi Minh (Vietnam)
}

\author{
Emilie Strady ${ }^{1,2}$ \&Vu Bich Hanh Dang ${ }^{3}$ \&Julien Némery ${ }^{1}$ \&Stéphane Guédron ${ }^{4}$ \& \\ Quoc Tuc Dinh ${ }^{2,3}$ \&Hervé Denis ${ }^{1} \&$ Phuoc Dan Nguyen $^{3}$
}

\begin{abstract}
The Saigon River, Southern Vietnam, crosses one of the most dynamic developing Megacity in Southeast Asia: Ho Chi Minh City (HCMC). The increased economic, industrial, and domestic developments may affect the environmental quality of water and halieutic resources. In this study, we evaluated the seasonal (dry and wet seasons) biogeochemical state of the Saigon River during two snapshot campaigns conducted along the river basin upstream from HCMC; the Saigon River was characterized by slightly acidic ( $\mathrm{pH}$ 5.7-7.7) and oxygendepleted water (dissolved oxygen (DO), $0.36-5.18 \mathrm{mg} \mathrm{l}^{-1}$ ). Nutrients $\left(\mathrm{N}-\mathrm{NH}_{4}=0.01-2.41, \mathrm{~N}-\mathrm{NO}_{3}=0.14-2.72\right.$, and $\mathrm{P}-$ $\left.\mathrm{PO}_{4}=\sim 0-0.42 \mathrm{mg} \mathrm{l}^{-1}\right)$, DOC $\left(2.2-8.0 \mathrm{mg} \mathrm{l}^{-1}\right)$, POC, and trace metal(oid) (As, $\mathrm{Cd}, \mathrm{Cr}, \mathrm{Cu}, \mathrm{Zn}$, and $\mathrm{Hg}$ ) concentrationswere low showing a good quality of the upstream river. In the urban center area, DO dropped to $0.03 \mathrm{mg} \mathrm{l}^{-1}$ accompanied with a rise of nutrient concentrations (e.g., $\mathrm{N}-\mathrm{NH}_{4}$, up to $17.7 \mathrm{mg} \mathrm{l}^{-1}$ ) likely originating from wastewater discharges. Trace metal concentrations also rose sharply (e.g., $\mathrm{Cr}$ and $\mathrm{Hg}$ rose up to 10-fold higher) in both water and sediments but remained under the
\end{abstract}

* Emilie Strady

emilie.strady@ird.fr

1 Université Grenoble Alpes/CNRS/IRD, LTHE UMR 5564, 38000 Grenoble, France

2 CARE-HCMUT, Ho Chi Minh City, Vietnam

3 Faculty of Environment, HCMUT, Ho Chi Minh City, Vietnam

4 Université Grenoble Alpes/CNRS/IRD, LTHE UMR 5564, 38000 Grenoble, France
World Health Organization (WHO) and Vietnamese concentration guidelines. In the downstream estuarine area, the intrusion of marine waters diluted water flowing from HCMC, leading water quality to return close to the state observed upstream from HCMC. In general, levels of nutrient and metal contaminations along the Saigon River during both seasons appear moderate regarding to Vietnamese and WHO guidelines although the urban area is highlighted as the major contributor for metal(oid) emissions. Finally, we showed that apart from wastewater and industrial discharges that affect the river quality, metal(oid) partitioning between solid and solution is controlled by the change in water geochemistry along the continuum during both seasons, such as $\mathrm{DO}$ (e.g., for As and $\mathrm{Cr}$ ) and $\mathrm{pH}$ (e.g., for $\mathrm{Pb}$ ) which drives their sorption/dissolution dynamics.

Keywords Tropical river · Water quality · Organic carbon . Mercury

\section{Introduction}

Ho Chi Minh City (HCMC; +8 million inhabitants), the economic capital of Vietnam, is one of the most dynamic Megacity in Southeast Asia. A $10 \%$ increase of its gross domestic products and $3 \%$ increase of urban growth per year over the last 10 years (e.g., population density of 3719 persons $/ \mathrm{km}^{2}$ in 2012) induced rapid economic, industrial, and domestic developments (General Statistics Office of Vietnam (GSO) 2014). Those increases had serious consequences in the environment and the river crossing the city, the Saigon River (van Leeuwen et al. 2015). Before being discharged directly to the river, only $10 \%$ of the total produced municipal wastewater is treated (Food and Agricultural Organization (FAO) 2014), while it was estimated at $1 \%$ the last decade (Marcotullio 2007). Industrial activities, estimated 
to about 30,000 small industrial production units and more than 800 large-scale factories gathered to 15 industrial zones, do not have adequate and effective wastewater treatment system (Coulthart et al. 2006) and are considered to be the dominant pollutant source (trace metal predominantly) to the Saigon River. In fact, Vo (2007) estimated a daily discharge of 260 tons of solid waste, including 25 tons of hazardous waste, $200,000 \mathrm{~m}^{3}$ of industrial wastewater, and $17,000 \mathrm{~m}^{3}$ of hospital effluent into the river. Furthermore, intensification of navigation, aquaculture (e.g., shrimp farming), and agriculture as paddy rice activities have led to the respective release of oils, nutrients, and organic compounds (pesticides, antibiotics) to the river (Sajor and Thu 2009). In this context, the survey and assessment of the Saigon River water quality is of major concern to anticipate the perseveration of the water and aquatic resources.

Sediments and suspended particles have been identified as key factors in contaminant transport from the continent to the ocean (Förstner and Salomons 2008). Their quality assessment (both suspended and deposited) is of major scientific concern (e.g., Apitz and Power 2002). Trace metals in aquatic environments originate naturally from erosion and soil leaching. They are also released by human activities through industrial, domestic, and urban discharges and agriculture activities. Because of their toxicity and their ability to accumulate in organisms, trace metals are major pollutants and are considered priority concerns by the European Water Framework Directive (EWFD) and the US Environmental Protection Agency (USEPA). At the ecosystem scale, trace metal riverine fluxes are comparable with the combination of anthropogenic trace metal fluxes to the atmosphere, soils, and waters (Viers et al. 2009). Nutrients, e.g., nitrogen $(\mathrm{N})$, phosphorus $(\mathrm{P})$, and carbon (C) are key elements in many biogeochemical cycles and are limiting elements of aquatic ecosystem processes (Wetzel 1983). Although they are basic natural constituents in aquatic ecosystems, excessive inputs of nutrients, e.g., mainly originating from human activities such agriculture, domestic, and sewage discharges can significantly accelerate the processes of eutrophication, e.g., the development of algal bloom and oxygen depletion in water (Conley et al. 2009).

In the Saigon River (Vietnam), several studies since the 1990s focused on measuring sporadically organic compounds and trace metals in sediments from urban canals and the city center part of the river (Phuong et al. 2008; Huy et al. 2003; Anh et al. 2003; Thuy et al. 2007; Minh et al. 2007) and more recently, in surface water in the entire Saigon River system (Chanpiwat and Sthiannopkao 2013). However, some of these studies (i) did not use ultra-clean techniques for trace metal analysis, (ii) did not provide analytical quality control as reproducibility, blank value, detection, and/or quantification limit, and (iii) conducted partial extraction without providing metal recovery from certified reference materials. Meybeck et al. (2007) observed an over-estimation of up to one order of magnitude for particulate metal (e.g., $\mathrm{Cd}, \mathrm{Hg}, \mathrm{Pb}$ ) when ultra-clean technique was not used during trace metal handling and analysis. Accordingly, it is complex to identify baseline concentrations and/or assess a historical evolution of metal concentrations in the Saigon River system from the abovecited references. In summary, these references pointed out an extreme contamination of sediments in urban canals, an absence of dilution effect on dissolved trace metal concentrations, and dissolved metal contamination in the middle stream of the river attributed by the authors to soil erosion, domestic, and industrial wastewater discharges. In general, the authors pointed out the difficulties and challenges of settling an integrative approach of river management and water governance in this area (Evans et al. 2012; van Leeuwen et al. 2015). In particular, the shortage of monitoring or integrating all compartments (i.e., deposited sediments, suspended sediments, water, and biota) and integrating the specific hydrological conditions of this system does not allow yet assessing the overall ecological and chemical states of this system.

The purpose of this study was to establish an evaluation of the biogeochemical state of the Saigon River. Two snapshot campaigns were performed along the river basin during two contrasted seasons (wet and dry seasons). The objectives were (i) to get an exhaustive inventory of dissolved and particulate nutrient and polymetallic concentrations which affect the quality of the river, (ii) to identify the impacted zones along the river basin, and (iii) to characterize the major processes controlling trace metal partitioning in the river for both wet and dry seasons. Accordingly, the temperature, $\mathrm{pH}$, dissolved oxygen (DO), conductivity, salinity, chlorophyll- $a$, phaeopigments, suspended particulate matter (SPM) concentrations, grain size distributions, nutrients, dissolved and particulate organic carbon and phosphorus, and trace metal(oid) $(\mathrm{Cr}, \mathrm{Ni}, \mathrm{Cu}, \mathrm{Zn}, \mathrm{As}, \mathrm{Cd}, \mathrm{Pb}, \mathrm{Hg}$, and $\mathrm{MMHg}$ ) concentrations were measured at 17 sites along the Saigon River in water (filtered and suspended matter) and sediment.

\section{Material and methods}

\section{Studyarea}

\section{The Saigon River}

The Saigon River, located in Southern Vietnam, is about $250 \mathrm{~km}$ long with a catchment area of $4717 \mathrm{~km}^{2}$ (Fig. 1). It originates from Phum Daung in southeastern Cambodia and flows to the Dau Tieng Reservoir, the 
fourth biggest reservoir in Vietnam $\left(120-270 \mathrm{~km}^{2}\right.$; 4701680 million $\mathrm{m}^{3}$ ). This reservoir supplies water for irrigation and tap water for HCMC. The regulation of its water discharges controls the intrusion of saline water downward of Phu Hoa to prevent damages on industries, especially on the water treatment plant at Phu Hoa. Downstream the reservoir, Saigon River flows through the economic capital Ho Chi Minh City where the river is connected to urban canals and confluences with the Dong Nai River to form the Nai Be River which flows through the Can Gio mangrove ( $+20,000$ ha; Biosphere UNESCO) and discharges into the South China Sea, $20 \mathrm{~km}$ north of the Mekong Delta. The area is dominated by monsoon seasons: a wet season from May to October and a dry season from November to April. In the wet season, the heaviest rainfall occurs in June and September with an average rainfall of 250 to $330 \mathrm{~mm} /$ month with a maximum of up to $683 \mathrm{~mm}$ (Dan et al. 2007). The mean annual flow rate is estimated at 54 or $85 \mathrm{~m}^{3} \mathrm{~s}^{-1}$, according to the authors (Nguyen et al. 2011). The Saigon River is affected by asymmetric semi-diurnal tides, which induces alternating river flow direction of up to $20 \mathrm{~km}$ downstream of the Dau Tieng Reservoir and salty water intrusion upward HCMC especially during dry season. The main tributaries of the Saigon River drain wastewater from industrial zones (e.g., the Thi Tinh River; Fig. 1) and wastewater from urbanized zones (e.g., urban canals; Fig. 1). The urban canals (700 km length) were built in the nineteenth century to ensure the connection of the city with the Mekong Delta, supply the city with freshwater, and control seasonal monsoon-relat- ed flood. They have been deteriorated since the last four decades due to natural and socioeconomic factors, in- cluding flood sediment deposition and maintenance ne- glect (Givental 2014).

\section{Sampling and handling}

Two snapshot sampling campaigns were conducted during dry and wet seasons, in March and October 2013, respectively. The choice of conducted snapshot campaigns during dry and rainy seasons over a long-term monitoring, besides conducting to different objectives, has disadvantages of disregarding local low temporal scale variability and physical and environmental features like tides, rain precipitation, and local water discharge change. However, it presents the advantage of giving a spatial high resolution of their distribution along the Saigon River basin, from the upstream of the basin to the sea. Accordingly, 17 sites (i.e., described in Table 1) were selected along the Saigon River and two of its tributaries, based on environmental characteristics and anthropogenic activities and were precisely identified by digital Global
Positioning System navigator (Fig. 1). At each site, water was sampled at $0-50 \mathrm{~cm}$ below surface using a $2.5-1$ Niskin-like bottle in the middle of the river either from a bridge or from a small boat. A first aliquot was immediately used to measure temperature, $\mathrm{pH}$, dissolved oxygen, conductivity, and salinity with a multi-parameter probe (WTW $3420^{\circledR}$ ). A second aliquot of river water was immediately filtered on $\mathrm{GF} / \mathrm{F}$ glass microfiber filters $\left(0.7 \mu \mathrm{m}\right.$ Whatman ${ }^{\circledR}$, pre-weighed and pre-heated at $\left.500{ }^{\circ} \mathrm{C}\right)$. The filters, used for suspended particulate matter (SPM) concentration and particulate organic carbon (POC) content determinations, were dried at $50{ }^{\circ} \mathrm{C}$, weighed back in the laboratory, and kept at room temperature. The filtrate was separated into two sub-aliquots, one for dissolved nutrient analyses stored in a $60-\mathrm{ml} \mathrm{bot-}$ tle and kept at $-18{ }^{\circ} \mathrm{C}$ and a second one for dissolved organic carbon (DOC) analyses stored acidified (2\% $(v /$ v) $\mathrm{HCl}$ ) at $4{ }^{\circ} \mathrm{C}$ in $15-\mathrm{ml}$ glass bottle (pre-burnt at 550 ${ }^{\circ} \mathrm{C}$ ). A third aliquot of water was filtered on GF/F glass microfiber filters $\left(0.7 \mu \mathrm{m}\right.$ Whatman $\left.{ }^{\circledR}\right)$, immediately folded, and kept in ice bags until being kept at $-20{ }^{\circ} \mathrm{C}$ in the dark for chlorophyll- $a$ measurements. A fourth aliquot of river water was filtered for trace metal analyses on preweighed PTFE filters $\left(0.20 \mu \mathrm{m}\right.$ Omnipore $\left.^{\circledR}\right)$ using an acid pre-cleaned $\left(10 \%(v / v)\right.$ Normapur $\left.\mathrm{HNO}_{3}\right)$ filtration device. Clean techniques were used to minimize contamination during sampling, handling, and storage (Patterson and Settle 1976). The filters, used for particulate trace metal (Metal ${ }_{\mathrm{SPM}}$ ) analyses, were kept in sterile plastic petri dishes at $-18{ }^{\circ} \mathrm{C}$. Back in the laboratory, the filters were freeze dried, weighed, and kept in the plastic petri dishes at room temperature. The filtrate, used for filtered trace metal $\left(\mathrm{Metal}^{\mathrm{F}}\right)$ analyses, was acidified $(2 \%(v / v)$ Normapur $\mathrm{HNO}_{3}$ ) and stored in a $30-\mathrm{ml}$ acid pre-cleaned PP bottle $\left(10 \%(v / v)\right.$ Normapur $\left.\mathrm{HNO}_{3}\right)$ at $4{ }^{\circ} \mathrm{C}$. A last aliquot of water was collected for total filtered mercury $\left(\mathrm{THg}^{\mathrm{F}}\right)$ and filtered monomethylmercury $\left(\mathrm{MMHg}^{\mathrm{F}}\right)$ analyses by filtration with Sterivex ${ }^{\circledR}$-HV $0.45 \mu \mathrm{m}$ sterile filters, collected in $250 \mathrm{ml}$ FEP bottles and acidified with $\mathrm{HCl}(0.5 \%(v / v)$ Millipore Seastar) (Parker and Bloom 2005). Water collection and handling was per- formed using appropriate ultra-clean techniques (Cossa and Gobeil 2000), and all materials in contact with sam- ples were acid washed $\left(5\right.$ days in $50 \%(v / v)$ Normapur $\mathrm{HNO}_{3}$ then 3 days in $10 \%(v / v)$ Normapur $\mathrm{HCl})$ and rinsed with ultrapure $\mathrm{MQ}^{\circledR}\left(18.2 \mathrm{M} \Omega \mathrm{cm}^{-1}\right)$ water before use.

At each site, sediments were also collected using a Shipek sediment grab sampler: the top $5 \mathrm{~cm}$ of the sediment was recovered using a plastic spatula, immediately placed in polyethylene bags, stored at $-18{ }^{\circ} \mathrm{C}$, freeze dried, and kept at room temperature. To notice, all materials were immediately stored in a cool box after handling 


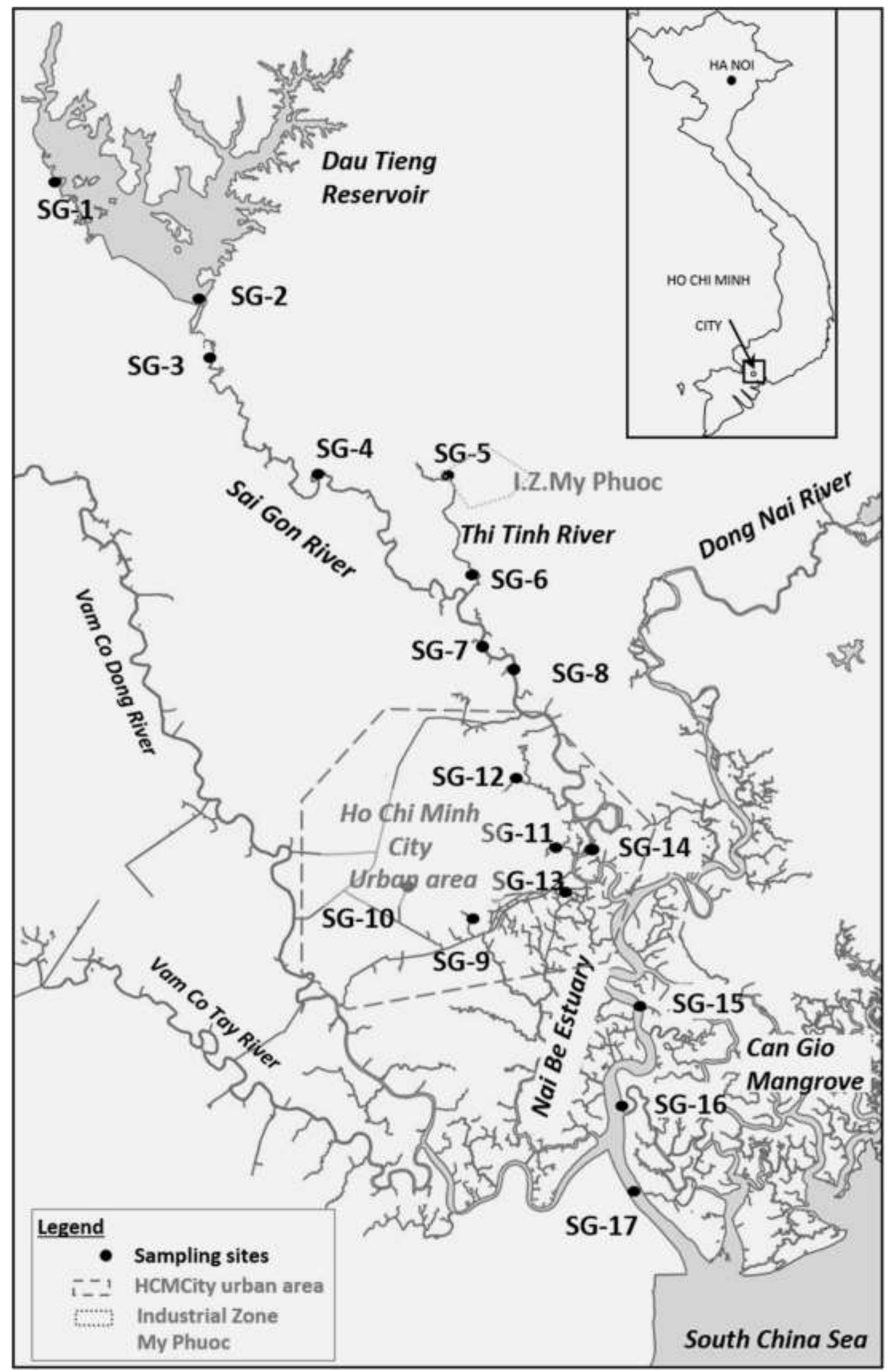

Fig. 1 Saigon River Basin's map and sampling site's location 
Table 1 Sampling site locations

\begin{tabular}{|c|c|c|c|c|}
\hline Sampling site names & Coordinates & & River stream & Dominating activities \\
\hline SG-1 (Dau Tien reservoir) & $\mathrm{N} 11^{\circ} 23^{\prime} 40^{\prime \prime}$ & E $106^{\circ} 14^{\prime} 37.5^{\prime \prime}$ & Reservoir & Fisheries \\
\hline SG-2 (Dau Tien output) & $\mathrm{N} 11^{\circ} 19^{\prime} 21.6^{\prime \prime}$ & E $106^{\circ} 20^{\prime} 45.2^{\prime \prime}$ & Saigon River & Fisheries \\
\hline SG-3 (Ben Cui) & $\mathrm{N} 11^{\circ} 16^{\prime} 44.2^{\prime \prime}$ & E $106^{\circ} 21^{\prime} 16.1^{\prime \prime}$ & Saigon River & Rubber plant activity \\
\hline SG-4 (Ben Suc) & $\mathrm{N} 11^{\circ} 09^{\prime} 19.6^{\prime \prime}$ & E $106^{\circ} 27^{\prime} 03.2^{\prime \prime}$ & Saigon River & Rubber plant activity \\
\hline SG-5 (Cau Da) & $\mathrm{N} 11^{\circ} 09^{\prime} 04^{\prime \prime}$ & E $106^{\circ} 35^{\prime} 15.7^{\prime \prime}$ & Tributary Thi Tinh & Industrial Zone Khu Công Nghiệp Mỹ Phước 2-3 \\
\hline SG-6 (Ong Co) & $\mathrm{N} 11^{\circ} 02^{\prime} 56.3^{\prime \prime}$ & E $106^{\circ} 36^{\prime} 37.9^{\prime \prime}$ & Tributary Thi Tinh & Industrial Zone Khu Công Nghiệp Mỹ Phước 2-3 \\
\hline SG-7 (Phu Cu ong) & $\mathrm{N} 10^{\circ} 58^{\prime} 47.5^{\prime \prime}$ & E $106^{\circ} 38^{\prime} 36.8^{\prime \prime}$ & Saigon River & Pre-urban area \\
\hline SG-8 (Phu Hoa) & N 1059'05.53" & E $106^{\circ} 37^{\prime} 10.6^{\prime \prime}$ & Saigon River & Water treatment plant \\
\hline SG-9 (Tau Hu) & $\mathrm{N} 10^{\circ} 44^{\prime} 54.3^{\prime \prime}$ & E $106^{\circ} 39^{\prime} 39.3^{\prime \prime}$ & Urban canal & Ho Chi Minh City area \\
\hline SG-10 (Lo Gom) & $\mathrm{N} 10^{\circ} 45^{\prime} 18.2^{\prime \prime}$ & E $106^{\circ} 38^{\prime} 15.3^{\prime \prime}$ & Urban canal & Ho Chi Minh City area \\
\hline SG-11 (Nhieu Loc) & N $10^{\circ} 47^{\prime} 09.4^{\prime \prime}$ & E $106^{\circ} 40^{\prime} 53.9^{\prime \prime}$ & Urban canal & Ho Chi Minh City area \\
\hline SG-12 (Tham Luong) & $\mathrm{N} 10^{\circ} 50^{\prime} 43.6^{\prime \prime}$ & E $106^{\circ} 38^{\prime} 18.03^{\prime \prime}$ & Urban canal & Ho Chi Minh City area \\
\hline SG-13 (Kenh Te) & $\mathrm{N} 10^{\circ} 45^{\prime} 06.6^{\prime \prime}$ & E $106^{\circ} 42^{\prime} 12.2^{\prime \prime}$ & Urban canal & Ho Chi Minh City area \\
\hline SG-14 (Bach Dang) & $\mathrm{N} 10^{\circ} 46^{\prime} 27.1^{\prime \prime}$ & E $106^{\circ} 42^{\prime} 26.6^{\prime \prime}$ & Saigon River & Ho Chi Minh City area \\
\hline SG-15 (Soai Rap) & $\mathrm{N} 10^{\circ} 37^{\prime} 17.8^{\prime \prime}$ & E $106^{\circ} 46^{\prime} 24.3^{\prime \prime}$ & Nha Be River & Aquaculture, paddy rice, salt production \\
\hline SG-16 (Vam Xa) & N $10^{\circ} 32^{\prime} 06.3^{\prime \prime}$ & E $106^{\circ} 45^{\prime} 00.2^{\prime \prime}$ & Nha Be River & Aquaculture, paddy rice, salt production \\
\hline SG-17 (Ly Nhon) & $\mathrm{N} 10^{\circ} 27^{\prime} 36.3^{\prime \prime}$ & E $106^{\circ} 46^{\prime} 11.1^{\prime \prime}$ & Nha Be River & Aquaculture, paddy rice, salt production \\
\hline
\end{tabular}

until being returned in the laboratory at the end of the sampling day, where they were immediately stored at respective temperature conditions.

\section{Laboratoryanalyses}

\section{Trace metal (Cr, $\mathrm{Ni}, \mathrm{Cu}, \mathrm{Zn}, \mathrm{As}, \mathrm{Cd}, \mathrm{Pb}, \mathrm{Al}, \mathrm{Fe})$ analyses}

Particulate trace metals on PTFE filters (MetalsPM) and representative sub-samples of surface sediments (Metal $_{\mathrm{SED}} ; 100 \mathrm{mg}$ of dried, powdered, and homogenized material) were analyzed by microwave digestion (NovaWave SCP Sciences ${ }^{\circledR}$, LTHE-OSUG Laboratory, Grenoble, France) based on USPA 3052 method using $6 \mathrm{ml} \mathrm{HCl}(12 \mathrm{M}), 3 \mathrm{ml} \mathrm{HNO}_{3}(14 \mathrm{M})$, and $2 \mathrm{ml} \mathrm{HF}(26 \mathrm{M})$ from trace metal-grade Fisher $^{\circledR}$. The Teflon reac-

tors were heated to $180 \pm 5^{\circ} \mathrm{C}$ (reached within $10 \mathrm{~min}$ ) for $15 \mathrm{~min}$. After cooling, the digested solution was poured into $30 \mathrm{ml}$ Savilex ${ }^{\circledR}$ vessel and evaporated until dry on an appropriate heating plate. Then, the residue was recovered using $0.250 \mathrm{ml} \mathrm{HNO}_{3}(14 \mathrm{M}$, trace met- al-grade Fisher ${ }^{\circledR}$ ) and $5 \mathrm{ml}$ of Milli-Q water for $30 \mathrm{~min}$ at $65^{\circ} \mathrm{C}$. After cooling and decantation, $3.5 \mathrm{ml}$ of superna- tant and $6.5 \mathrm{ml}$ of Milli-Q water were poured into $15 \mathrm{ml}$ acid precleaned PP tube. Trace metal concentrations $(\mathrm{Cr}, \mathrm{Ni}, \mathrm{Cu}, \mathrm{Zn}$, $\mathrm{As}, \mathrm{Cd}, \mathrm{Pb}$ ) were measured by ICP-MS (Elan DRC II Perkin Elmer, TERA Environment Laboratory Fuveau France) while $\mathrm{Al}$ and $\mathrm{Fe}$ concentrations were mea- sured by ICPAES (Varian 720 ES, LTHE-OSUG Laboratory, Grenoble, France) using for both cases external calibration. The analytical quality for particulate trace metal measurements was assured by analyzing duplicates $(n=7$ error $<4 \%)$ and certified reference materials (CRM) GBW-07323 (accuracy $N=5$ : As, $8 \%$; Cd, $7 \%$;

$\mathrm{Cr}, 14 \%$; $\mathrm{Cu}, 11 \%$; Ni, $9 \%$; Pb, $7 \%$; $\mathrm{Zn}, 12 \%$ ) and MESS-3 (accuracy $N=4$ : As, $9 \%$; Cd, $12 \%$; Cr, $8 \%$; Cu, 8 $\%$; Ni, $8 \%$; Pb, $11 \%$; Zn, $10 \%)$.

Metal $_{F}$ concentrations were directly measured by ICP-MS (Elan DRC II Perkin Elmer), using external calibration and, when the salinity of the sample was up to 1 , they were determined without any prior dilution using Kinetic Energy Discrimination-Argon Gas Dilution (KED-AGD mode) with the Thermo Scientific iCAPQ ICP-MS (Plateforme AETEHydroSciences/OSU OREME, Montpellier-France). An internal solution, containing $\mathrm{Sc}, \mathrm{Ge}, \mathrm{In}$, and Bi was added on-line to the samples to correct signal drifts.

\section{$\mathrm{THg}_{F}, \mathrm{MMHg}_{F}$, and particulate mercury $\mathrm{THg}_{S E D}$ analyses}

Total particulate $\mathrm{Hg}$ concentrations $\mathrm{THg}_{\mathrm{SED}}$ were determined by atomic absorption spectrophotometry after dry mineralization and gold amalgamation using an automatic mercury analyzer (Altec, Model AMA 254 ISTerre-OSUG Laboratory, Grenoble, France) with a relative precision of $\pm 10 \%$ (Guédron et al. 2009). The analytical quality was insured by analyzing every sample twice (the measurement error was about $5 \%$ and always below $10 \%$ ), by analyzing CRMs (MESS-3, $n=4,3 \%$ accuracy; GBW-07323, $n=4,9 \%$ accuracy), and by obtaining a detection limit $\left(3 \mathrm{SD}_{\mathrm{blk}}\right)$ of $0.010 \mu \mathrm{g} \mathrm{g}^{-1}$. 
Filtered total mercury concentrations $\left(\mathrm{THg}_{\mathrm{F}}\right)$ were determined by cold vapor atomic fluorescence spectrometry (CV-AFS) after conversion of all mercury species into $\mathrm{Hg}^{0}$ (Bloom and Fitzgerald 1988) followed by de- tection using a Tekran $^{\circledR} \quad$ (Model 2500 ISTerre-OSUG Laboratory, Grenoble, France) mercury detector equipped with a high-sensitivity mirrored quartz fluorescence cuvette. The principles of the methods follow the Bloom and Fitzgerald (1988) gold amalgamation meth- od. $\mathrm{QA} / \mathrm{QC}$ for $\mathrm{THg}_{\mathrm{F}}$ was checked by repeating the analysis of the CRM ORMS-5. Concentrations found (26.6 \pm 1.1 $\mathrm{pg} \mathrm{g}^{-1}, N=12$ ) agreed with the certified concentration $\left(26.2 \pm 1.3 \mathrm{pg} \mathrm{g}^{-1}\right)$. The analytical quality for $\mathrm{THg}_{\mathrm{F}}$ measurements was assured by analyzing sev- eral samples twice with measurement error on replicates $(n=15)$ always lower than $15 \%$. Blank replicate con- centrations were $0.053 \pm 0.006 \mathrm{ng} \mathrm{l}^{-1}(n=12)$, and the detection limit $\left(3 \mathrm{SD}_{\mathrm{blk}}\right)$ was $0.02 \mathrm{ng}^{-1}$.

Filtered and particulate monomethylmercury $\left(\mathrm{MMHg}_{\mathrm{F}}\right.$ and $\mathrm{MMHg}_{\mathrm{SED}}$ ) concentrations were analyzed using a purge and trap-gas chromatograph-atomic absorption spectrophotometry analyzer (MERX System, Brooks Rand ${ }^{\circledR}$ ISTerre-OSUG Laboratory, Grenoble, France) equipped with an autosampler after being derivatized at $\mathrm{pH} 4.0$ using $180 \mu \mathrm{l}$ of a daily prepared $1 \%$ sodium propylborate solution (Sigma Aldrich) (Guédron et al. 2014a, b). For solids, about $100 \mathrm{mg}$ of solid samples was first extracted with $5 \mathrm{ml}$ $\mathrm{HNO}_{3}(6 \mathrm{~N})$ in clean $15-\mathrm{ml}$ Falcon tubes (VWR) at $60{ }^{\circ} \mathrm{C}$ during $2 \mathrm{~h}$. Filtered water $(40 \mathrm{ml})$ or diluted sample aliquots of the extraction solution for solids were then transferred into 40-ml glass vials equipped with Teflon septa. $\mathrm{MMHg}$ contents for all samples were duplicated and quantified using the standard addition technique (three standard additions for each sample). MMHg measurement traceability and accuracy were checked against ERM CC580 CRM (Institute for Reference Materials and Measurements (IRMM)). MMHg concentrations measured for this material $\left(75.9 \pm 4.9 \mathrm{ng} \mathrm{Hg} \mathrm{g}^{-1}, N=9\right)$ were within $10 \%$ of the certified values ( $75 \pm 4 \mathrm{ng} \mathrm{Hg} \mathrm{g}^{-1}$ ). The measurement error on replicates was usually about $10 \%$ and was always lower than $15 \%$. The blanks were always below $1 \mathrm{pg}^{-1}$ ( $N$ $=22)$, the quantification limit $\left(10 S D_{\mathrm{blk}}\right)$ was

$0.004 \mathrm{ng} \mathrm{l}^{-1}$, and the absolute detection was $1 \mathrm{fmol}$ of MMHg.

\section{Particulate and dissolved organic carbon analyses}

GF/F filters and $30 \mathrm{mg}$ of dried, powdered, homoge- nized sediment were acidified with $\mathrm{HCl}(2 \mathrm{M})$ to re- move carbonates and dried at $60{ }^{\circ} \mathrm{C}$ for $24 \mathrm{~h}$. Samples were then analyzed with a LECO CS-125 analyzer (EPOC Laboratory, Talence France) with precision better than 5 $\%$, according to the method described by
Etcheber et al. (1999). POC contents are expressed as percentage of dry weight of SPM (POC\%). Dissolved carbon was determined by high-temperature catalytic oxidation with a TOC-VCSN Shimadzu analyzer (ISTerreOSUG Laboratory, Grenoble, France) (Sigumura and Suzuki 1988). Analytical accuracy was higher than $5 \%$.

\section{Orthophosphates, nitrates, and ammonium analyses}

Orthophosphates $\left(\mathrm{P}-\mathrm{PO}_{4}\right)$ were analyzed according to the ascorbic acid-molybdate blue method (Murphy and Riley 1962) and measured spectrophotometrically. Ammonium $\left(\mathrm{N}-\mathrm{NH}_{4}\right)$ was analyzed directly on site using the Hach-Lang kit photolab and according to standard colorimetric method (APHA 1995). Nitrate $\left(\mathrm{N}-\mathrm{NO}_{3}\right)$ were measured by ion chromatography (Metrohm ion chromatography unit). Reproducibility for replicate measurements was better than 5 $\%$ for all dissolved nutrient analysis.

\section{Total particulate and particulate inorganic phosphorus analyses}

The total particulate P (TPP) content of sediment was determined using a high-temperature $/ \mathrm{HCl}$ extraction technique (Aspila et al. 1976) prior to phosphate measurement by colorimetric method (Murphy and Riley 1962). To estimate particulate inorganic P (PIP), the analysis was similar to that of TPP, except that the hightemperature organic $\mathrm{P}$ mineralization was omitted (Svendsen et al. 1993). Reproducibility for replicate measurement was better than $5 \%$ for TPP and PIP.

\section{Chlorophyll-a and phaeopigments analyses}

Chlorophyll- $a$ and phaeopigments were analyzed by spectrophotometry (665 and $750 \mathrm{~nm}$ absorbance, respectively) after acetone $(90 \%)$ extraction according to the method described by Aminot and Kerouel (2004). Because of storage issues, only data from the wet sea- son are shown in this paper.

\section{Grain size distribution analyses}

Grain size distribution was measured using a laser diffraction sizer after being submitted to a 3-min ultrasonic agitation (Malvern, Mastersizer 2000 LTHE-OSUG Laboratory, Grenoble, France). Reproducibility for triplicate measurements was better than $5 \%$.

\section{Enrichmentfactor}

The degree of metal enrichment in sediments was assessed using the enrichment factor (EF) which allows differentiating 
natural geochemical background to anthropogenic inputs (Zhang and Liu 2002). Previously, trace metal concentrations in sediments were normalized with $\mathrm{Al}$ to compensate natural variability due to grain size variations (e.g., mineral composition) and to detect any anthropogenic metal contributions (e.g., Lohring 1991). Then, EF was defined as the ratio of Al-normalized metal concentrations in sediments over Al-normalized ratio in a geochemical background reference, defined as SG-3 site and located upstream of the Saigon River basin (showing a good repeatability; personal data). To validate the SG-3 site as a "natural" geochemical background, we calculated EF using UCC values (Wedepohl 1995), determined the $\mathrm{EF}_{\mathrm{UCC}} / \mathrm{EF}_{\mathrm{SG}-3}$ ratio $\left(\mathrm{EF}^{\mathrm{As}}=2 ; \mathrm{EF}^{\mathrm{Cd}}=0.6 ; \mathrm{EF}^{\mathrm{Cr}}=2.7\right.$; $\mathrm{EF}^{\mathrm{Cu}}=1.0 ; \mathrm{EF}^{\mathrm{Ni}}=1.3 ; \mathrm{EF}^{\mathrm{Pb}}=0.7 ; \mathrm{EF}^{\mathrm{Zn}}=3.1$; $\mathrm{EF}^{\mathrm{Hg}}=1.4$ ), and concluded that SG-3 is a good natural background sediment, showing even less enrichment than UCC for $\mathrm{Cr}$ and $\mathrm{Zn}$. Thus, a value of EF between 0.5 and 1.5 suggests natural weathering processes (Zhang and Liu 2002). In contrary, EF $>1.5$ values suggest enrichment from anthropogenic source. More precisely, the $1.5<\mathrm{EF}<3$ interval indicates a minor enrichment, the $3<\mathrm{EF}<5$ one for a moderate enrichment and the $5<\mathrm{EF}<10$ one for a moderately severe enrichment until $\mathrm{EF}<50$ values which indicate an extremely severe enrichment.

\section{Results and discussions}

This study presents for the first time an integrative dataset on filtered water, SPM, and sediment from the Saigon River system (Supplementary Table). Measured physico- chemical parameters, e.g., temperature $\mathrm{pH}$, dissolved oxy- gen, conductivity, chlorophyll- $a$ and phaeopigments, salin- ity (Fig. 2), SPM concentrations and grain size distribu- tions (Fig. 2), carbon (DOC and POC) and nutrient (e.g., N-NH4, $\mathrm{N}-\mathrm{NO}_{3}, \mathrm{P}-\mathrm{PO}_{4}, \mathrm{TPP}, \mathrm{PIP}$ ) concentrations (Fig. $\underline{3}$ ), and trace metal concentrations, e.g., filtered and partic- ulate $\mathrm{Cr}$, $\mathrm{Ni}$, $\mathrm{Cu}, \mathrm{Zn}, \mathrm{As}, \mathrm{Cd}, \mathrm{Pb}, \mathrm{Hg}$, and MMHg (Fig. aa, b) exhibit significant level fluctuation from the reser- voir to the sea. Accordingly, three geographic zones can be defined: upstream from Saigon River (SG-1 to SG-8), the urban HCMC area (SG-9 to SG-14), and the estuarine environment (SG-15 to SG-17). For clarity, results will be discussed within each of these zones and an overview on the potential impact of the HCMC Megacity on the Saigon River will be discussed on the last portion of this paper.

Saigon River upstream of HCMC: a naturally acidic river with a good quality state

The upper part of the Saigon River, from the Dau Tieng reservoir to Phu Hoa (i.e., SG-1 to SG-8), is weakly affected by local anthropogenic activities (e.g., rubber plants and agriculture) as illustrated by low $\mathrm{N}-\mathrm{NH}_{4}, \mathrm{~N}-$ $\mathrm{NO}_{3}, \mathrm{P}-\mathrm{PO}_{4}$, and DOC concentrations (respectively $0.01-$ 2.41, 0.14-2.72, $\sim 0-0.42$, and 2.2-8.0 $\mathrm{mg} \mathrm{l}^{-1}$; Figs. 2 and 3; Supplementary data 1 ). SPM concentrations are also low $\left(6-183 \mathrm{mg} \mathrm{l}^{-1}\right)$, despite a visual turbid aspect of the water. The upstream Dau Tieng reservoir (SG-1) differs from the downstream Saigon River with slightly more alkaline water (7.2 and 8.3), higher Chl- $a\left(16 \mu \mathrm{gl}^{-1}\right)$, dissolved oxygen (DO; $7.8 \mathrm{mg} \mathrm{l}^{-1}$ ), and POC concentrations $(17.8 \%)$, which are typical of algal development in the reservoir. Downstream the reservoir, Chl- $a$ concentrations drop to below detection limits in the river and the resulting degraded pigments (i.e., phaeopigments; Fig. $\underline{3}$ ) rise accordingly (up to $1068 \mu \mathrm{g} \mathrm{l}^{-1}$ ), indicating surface grazing activity (Jeffrey 1980). pH and DO values decrease significantly in this area (down to 5.7 and $0.36 \mathrm{mg} \mathrm{l}^{-1}$ ), with opposite seasonal trends: $\mathrm{pH}$ being more acidic during the rainy season whereas water being more oxygen depleted during dry season. The Saigon River acidification is closely related to the leaching of the surrounding acid sulfate soils during rainy seasons (Nguyen et al. 2011) while the intense oxygen depletion during the dry season could be the results of enhanced nitrification along the river network (Garnier et al. 2007). Indeed, besides the Thi Tinh River, i.e., a tributary entering the Saigon River upstream of SG-7, shows a rise in $\mathrm{N}-\mathrm{NH}_{4}$ and $\mathrm{P}-\mathrm{PO}_{4}$ concentrations (SG-5, 2.41 and $0.42 \mathrm{mg} \mathrm{l}^{-1}$, respectively), which is likely related to local domestic and industrial (i.e., textile, leather, electronics, plastics, and food industries) discharges from the industrial zone of My Phuoc. Then, concentrations return to baseline levels except for $\mathrm{N}-\mathrm{NO}_{3}$ which remains slightly higher in the downstream part (i.e., SG-5 toSG-8).

Considering the $\mathrm{pH}$ and DO values, the Saigon River water would state a bad quality according to EWFD and Vietnamese National Technical Regulation on Surface Water Quality (QCVN 2008). However, according to the nutrient levels, the water quality in the upper Saigon, except SG-5, states good given the EWFD numerical standard of water quality (WFD 2000/60/CE; limits: $\mathrm{N}-\mathrm{NH}_{4}$, $0.4 \mathrm{mg} \mathrm{l}^{-1} ; \mathrm{N}-\mathrm{NO}_{3}, 2.25 \mathrm{mg} \mathrm{l}^{-1}$; and $\mathrm{P}-\mathrm{PO}_{4}, 0.16 \mathrm{mg} \mathrm{l}^{-1}$ respectively) and Vietnamese QCVN (2008; QCVN 08:2008/BTNMT; A2, N-NH, $0.2 \mathrm{mg} \mathrm{l}^{-1} ; \mathrm{N}-\mathrm{NO}_{3}$, $5 \mathrm{mg} \mathrm{l}^{-1}$; and $\mathrm{P}-\mathrm{PO}_{4}, 0.2 \mathrm{mg} \mathrm{l}^{-1}$ ). This diagnostic is confirmed given the moderate DOC concentrations (up to $3.5 \mathrm{mg} \mathrm{l}^{-1}$ ) and POC content in sediment and SPM (from 1 to $7.7 \%$ ) with regard to the range of POC\% measured in World river values (Meybeck et al. 2005).

Besides nutrients, filtered trace metal concentrations measured in the upper Saigon River $\left(\left(\mu \mathrm{g} \mathrm{l}^{-1}\right) \mathrm{As}_{\mathrm{F}}, 0.32\right.$ 1.66; $\mathrm{Cd}_{\mathrm{F}}$, n.d. $-0.163 ; \mathrm{Cr}_{\mathrm{F}}, 0.036-0.849 ; \mathrm{Cu}_{\mathrm{F}}, 0.92-13.3$; $\mathrm{Ni}_{F}, 0.53-4.04 ; \mathrm{Pb}_{\mathrm{F}}$, D.L.-1.00; $\mathrm{Zn}_{\mathrm{F}}, 4.2-107$ : Fig. $4 \mathrm{a}, \mathrm{b}$; 

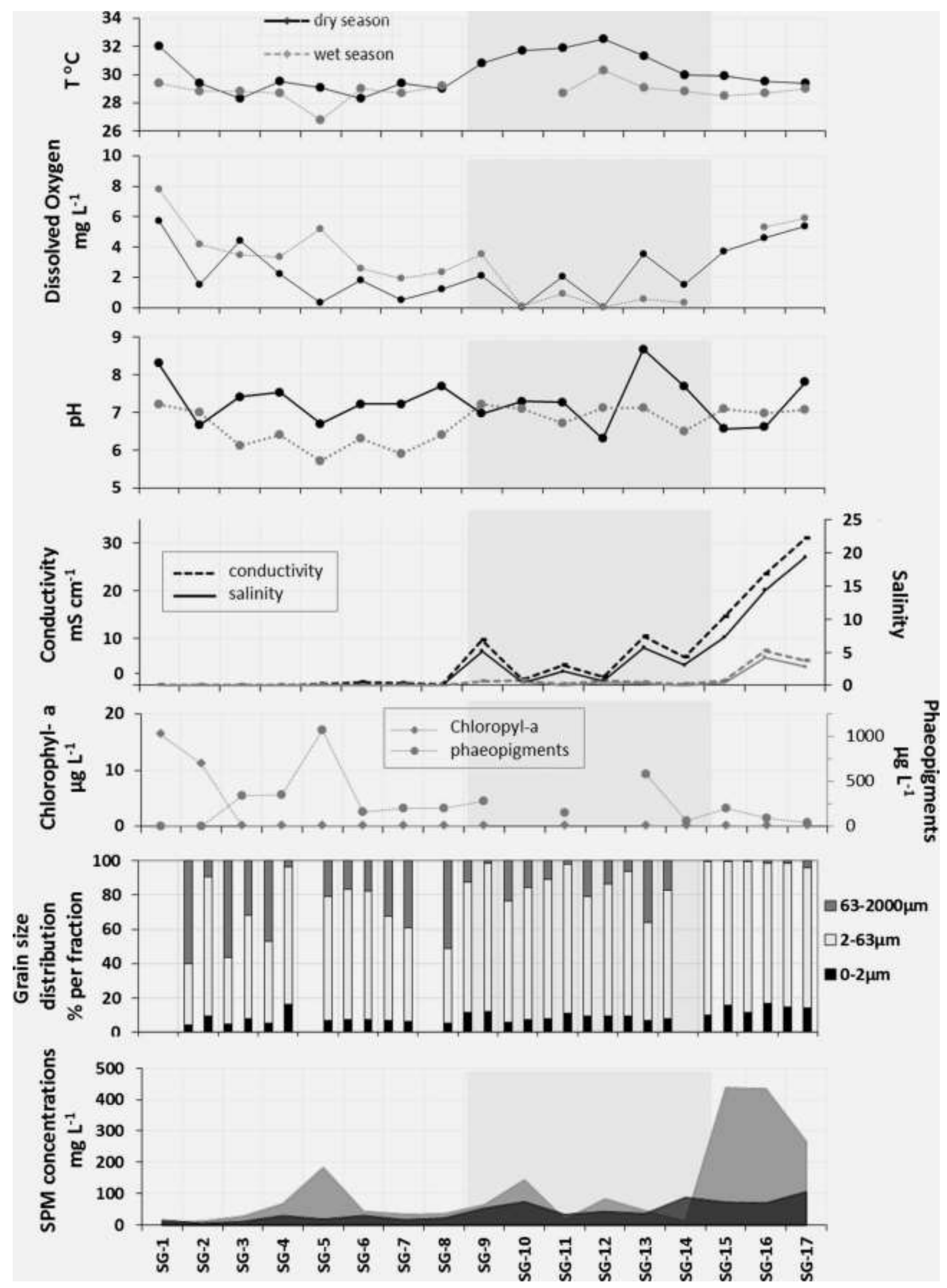
Fig. 2 Physico-chemical parameters measured in the 17 sampling sites during dry (black) and rainy (gray) seasons: temperature, dissolved oxygen, $\mathrm{pH}$, conductivity, salinity, chlorophyl- $a$ and phaeopigment concentrations, grain size distribution per fraction, and SPM concentrations. The light gray area represents the urban zone

Supplementary data 2) are within mean World river values (Viers et al. 2009) for $\mathrm{Cd}_{\mathrm{F}}, \mathrm{Cu}_{\mathrm{F}}, \mathrm{As}_{\mathrm{F}}, \mathrm{Cr}_{\mathrm{F}}$, and $\mathrm{Pb}_{\mathrm{F}}$, slightly higher for $\mathrm{Ni}_{\mathrm{F}}$, or two-orders of magnitude higher for $\mathrm{Zn}_{\mathrm{F}}$. Only high $\mathrm{Cr}_{\mathrm{F}}$ are measured during dry season in the upper Thi Tinh River (SG-5; $11.15 \mu \mathrm{g} \mathrm{l}^{-1}$ ) likely related as for ammonia to discharges from the Industrial Zone of $\mathrm{My}$ Phuoc. Globally, concentrations are largely under the WHO level recommendations (WHO 2011) and the Vietnamese QCVN (2008; BTNMT) and are in the same range of concentrations measured in this environment by Chanpiwat and Sthiannopkao (2013). In particular, As concentrations remain far below concentrations reported in Vietnamese aquifers (Berg et al. 2008) and WHO guidelines $\left(10 \mu \mathrm{g} \mathrm{l}^{-1}\right)$. Although $\mathrm{THg}_{\mathrm{F}}$ concentrations $\left(8.9 \pm 4.5 \mathrm{ng} \mathrm{l}^{-1}\right)$ remain moderately elevated being in the higher range of concentrations measured in worldwide pristine rivers, high concentration of $\mathrm{MMHg}_{\mathrm{F}}$ (reaching $1.2 \mathrm{ng} \mathrm{l}^{-1}$ representing $7 \%$ of $\mathrm{THg}_{\mathrm{F}}$ ) was measured in the Dau Tieng reservoir (SG-1) being in the range of reported human-contaminated waters in lakes and rivers (Balogh and Nollet 2008; Balogh et al. 2006; Cossa et al. 1994; Garcia Bravo et al. 2015; Guédron et al. 2014a). Then, in the following upper Saigon River, concentration dropped (SG-4 $=0.08 \mathrm{ng} \mathrm{l}^{-1}$ representing $1 \%$ of $\mathrm{THg}$ ) to the common range of concentration for pristine rivers and rose sharply downstream $\left(\mathrm{SG}-7=0.58 \mathrm{ng} \mathrm{l}^{-1}\right.$ representing $7 \%$ of THg). Such elevated MMHg concentrations in the Dau Tieng reservoir and at SG-7 is likely related to methylation of $\mathrm{Hg}$ in the reservoir and in the acidic and DOdepleted waters of the downstream part. Indeed, water of the Saigon River combines all the geochemical conditions that favor $\mathrm{Hg}$ methylation by sulfate-reducing bacteria (e.g., acidic and hypoxic conditions) (Benoit et al. 1999; 2003). Particulate trace metal concentrations are higher in SPM compartment than in sediment for all metals and both seasons (Fig. ㄸa a, b; Supplementary data 2). Measured $\mathrm{As}_{\mathrm{SPM}}, \mathrm{Cd}_{\mathrm{SPM}}, \mathrm{Cr}_{\mathrm{SPM}}, \mathrm{Cu}_{\mathrm{SPM}}, \mathrm{Ni}_{\mathrm{SPM}}, \mathrm{Pb}_{\mathrm{SPM}}$, and $\mathrm{Zn}_{\mathrm{SPM}}$ concentrations ((mg kg$\left.{ }^{-1}\right) \mathrm{As}_{\mathrm{SPM}}, 3.6-26$; $\mathrm{Cd}_{\mathrm{SPM}}$, n.d.-0.71; $\mathrm{Cr}_{\mathrm{SPM}}, 65-224 ; \mathrm{Cu}_{\mathrm{SPM}}, 23-87$; $\mathrm{Ni}_{\mathrm{SPM}}, 22-80 ; \mathrm{Pb}_{\mathrm{SPM}}, 15-68 ; \mathrm{Zn}_{\mathrm{SPM}}, 175-602$ : Fig. $4 \mathrm{a}$, b; Supplementary data 2) are in the average Metal ${ }_{S P M}$ concentrations of World river values (Viers et al. 2009) and close to the low human-impacted Mekong River (Gaillardet et al. 1999; Censi and Martin 2004). For Cr, both higher $\mathrm{Cr}_{\mathrm{SPM}}$ and $\mathrm{Cr}_{\mathrm{F}}$, are measured at SG-5 dry season and SG-6 rainy season supporting local Cr pollution from the industrial zone of My Phuoc. However, considering the low SPM concentrations in the Saigon River water (10-100 $\mathrm{mg} \mathrm{l}^{-1}$; Supplementary data 1 ), the Metal $_{\text {SPM }}$ concentrations expressed in milligrams per ${ }^{-1}$ iter are three orders of magnitude lower (i.e., ppb range) than Metal $_{\text {SED }}$ (i.e., ppm range) and in the same order of magnitude than the Metal F. Metal $_{\mathrm{SED}}$ concentrations do not exhibit particular trend between dry and rainy seasons: variations are mostly related to grain size distribution variability at the same sampling site (Figs. $\underline{2}$ and $\underline{4}$ a, b). From the reservoir to SG-8, Metal $\mathrm{SED}$ concentrations slightly increase, except for AsSED and for $\mathrm{Cd}_{\mathrm{SED}}$ and $\mathrm{Cu}_{\text {SED }}$ during dry season (Fig. $4 \mathrm{a}, \mathrm{b}$; Supplementary data 2). In opposition to filtered $\mathrm{Hg}$, both $\mathrm{Hg}_{\mathrm{SED}}$ and $\operatorname{MMHg}_{S E D}(<1 \% \mathrm{THg})$ (Fig. $4 \mathrm{a}, \mathrm{b}$; Supplementary data 2 ) are in the range of natural background sediment concentrations reported in the Mekong sediments and elsewhere (Castelle et al. 2007; Guédron et al. 2014b; Sonke et al. 2010).

In order to better understand the partitioning of metals between the filtered and particulate phases, we examined the coefficient partition $K_{\mathrm{d}}\left(=\mathrm{Metal}_{\mathrm{SPM}} / \mathrm{Metal}_{\mathrm{F}}\right.$ ) (Turner et al. 1993). $\log K_{\mathrm{d}}$ are higher during the rainy season than the dry season likely due to higher $\mathrm{pH}, \mathrm{DO}$, and SPM concentrations which may decrease the metal solu- bility and favor the sorption of dissolved metals as illus- trated by higher MetalspM concentrations during rainy season (Fig. $4 \mathrm{a}, \mathrm{b}$ ). Indeed, $\log K_{\mathrm{d}}$ of $\mathrm{Cr}$ exhibits a shift of one order of magnitude from the reservoir to SG-8 and presents a positive correlation with dissolved oxygen (Fig. 5a), illustrating the role of oxygenation on $\mathrm{Cr}$ partitioning and co-precipitation in the water column. In addition, $\log K_{\mathrm{d}}$ of As is also significantly higher during the wet season (Fig. 4a), likely due to a higher abundance of Fe oxi(hydr)oxides with increasing DO (Fig. $\underline{5}$ g) which enhance the sorption or (co)precipitation of $\mathrm{As}^{\mathrm{F}}$ (Fig. $\underline{5} \mathrm{~b}$ ) on these neo-formed oxides (Berg et al. 2008). Besides, the one unit drop for $\log K_{\mathrm{d}}$ of $\mathrm{Pb}$ between the dry and wet seasons is likely related to change in $\mathrm{pH}$ (Fig. $\underline{5} \mathrm{c}$ ) as $\mathrm{Pb}$ solubility decreases with $\mathrm{pH}$ (Turner et al. 1981). Finally, besides the seasonal influence on physico-chemical parameters, organic ligands appear to play a major role in the partitioning of $\mathrm{Cu}, \mathrm{Cr}$, and As (Fig. $\underline{5} \mathrm{a}-\mathrm{d}$ ). Metal $\mathrm{SED}_{\mathrm{SED}}$ concentrations seem more related to POC contents than to sediments grain size distribution, as shown for $\mathrm{Cu}_{\mathrm{SED}}$ (Fig. e) .

HCMC urban area: a system impacted by urban and industrial contaminants

The urban area (SG-9 to SG-14) is characterized by three main features: (i) an abrupt shift of physico-chemical parameters accompanied with a rise in nutrients and trace metal concentrations in all compartments; (ii) a high 

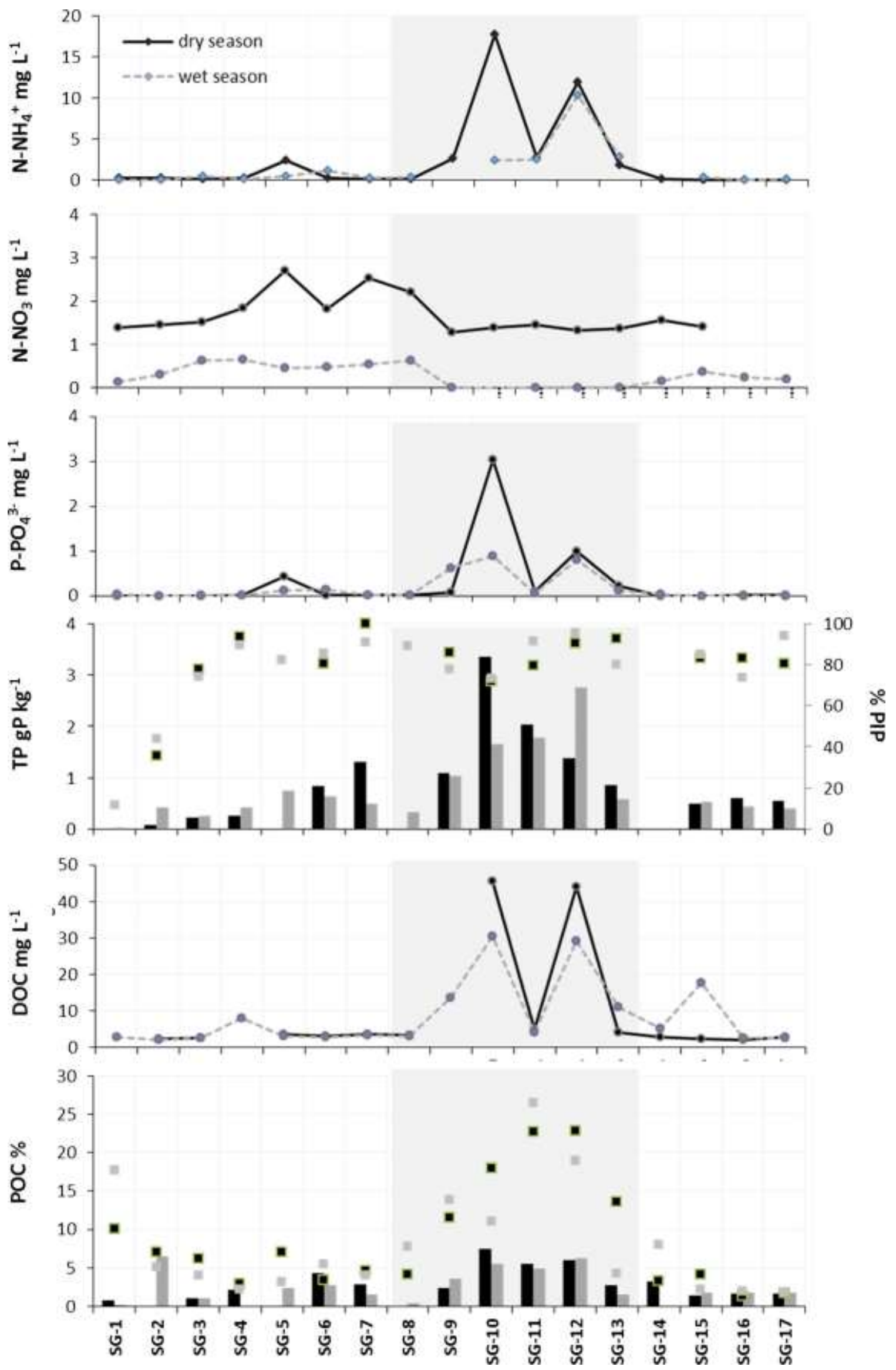
Fig. $3 \mathrm{C}, \mathrm{N}, \mathrm{P}$ concentrations measured in the 17 sampling sites during dry (black) and rainy (gray) seasons: $\mathrm{N}-\mathrm{NH}^{4+}, \mathrm{N}-\mathrm{NO}^{3}, \mathrm{P}-\mathrm{PO}_{4}^{3-}$, TP, PIP, DOC, and POC. Dot lines, histograms and square represent dissolved phase, sediment phase, and SPM phase, respectively. The light gray area represents the urban zone

variability of measured concentrations between Canals; and (iii) low nutrients and metal concentrations in the main river (SG-14) downstream the confluences with canals.

In the urban area, both canal waters (SG-9 to SG-13) and Saigon River water (SG-14) highlight an organic pollution state for both seasons characterized by high $\mathrm{P}-\mathrm{PO}_{4}$, $\mathrm{N}-\mathrm{NH}_{4}$, and DOC concentrations (up to $3.03,17.7$, and $46 \mathrm{mg} \mathrm{l}^{-1}$, respectively) and oxygen depleted (down to $0.03 \mathrm{mg} \mathrm{l}^{-1}$ ) waters. Similarly, POC $\mathrm{SPM}, \mathrm{POC}_{\mathrm{SED}}$, and TPP are high (up to 26.5, 7.5, and $3.35 \mathrm{~g} \mathrm{P} \mathrm{kg}^{-1}$, respec-

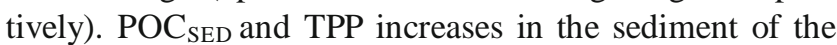
canals indicated an important storage of organic carbon
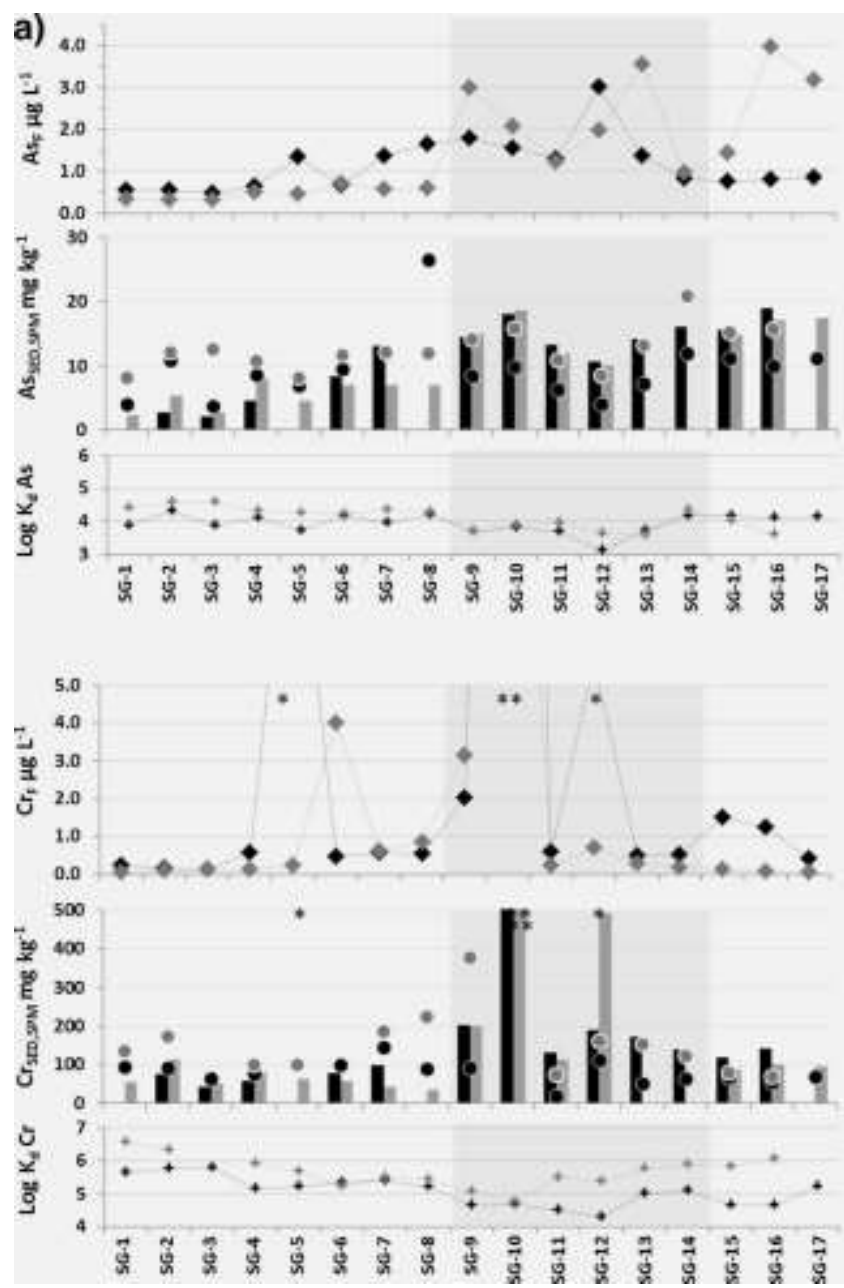

Fig. 4 Metal $_{F}$, Metal ${ }_{S E D}$, and Metal ${ }_{S P M}$ concentrations and $\log K_{{ }_{d}}$ determined in the 17 sampling sites during dry (black) and rainy (gray) seasons for a As, $\mathrm{Cd}, \mathrm{Cu}$, and $\mathrm{Cr}$ and b Ni, $\mathrm{Pb}, \mathrm{Zn}, \mathrm{THg}$, and MMHg. Dot lines, histograms, and square, represent dissolved phase, sediment phase, and SPM phase, respectively, except for $\mathrm{THg}$ and $\mathrm{MMHg}$ where and phosphorus in the sediments. Accumulation of organic carbon and phosphorus is likely occurring during the dry season where adsorption onto SPM and sedimentation are high in tropical deltaic rivers (Trinh et al. 2012). Such contaminated conditions result from the release of untreated waste waters and intense heterotrophic activity, which is likely to occur in such urban impacted tropical river, like in the Nhué River urban system downstream Hanoï (Trinh et al. 2009). The particular low $\mathrm{N}-\mathrm{NO}_{3}$ values $(0-$ $1.47 \mathrm{mg} \mathrm{l}^{-1}$ ) being lower than upstream for both seasons are suggestively related to enhanced denitrification rate in these anoxic and warm stagnant tropical waters (Dan et al. 2007), as reported in the Red River Delta by Luu et al. (2010). Amongst the different canals sampled in the city, both physico-chemical parameter and nutrient measurement shows up important heterogeneity. In particular, anoxic waters and extremely high $\mathrm{N}-\mathrm{NH}_{4}, \mathrm{P}-\mathrm{PO}_{4}$ (according to Vietnamese QCVN 2008), TPP
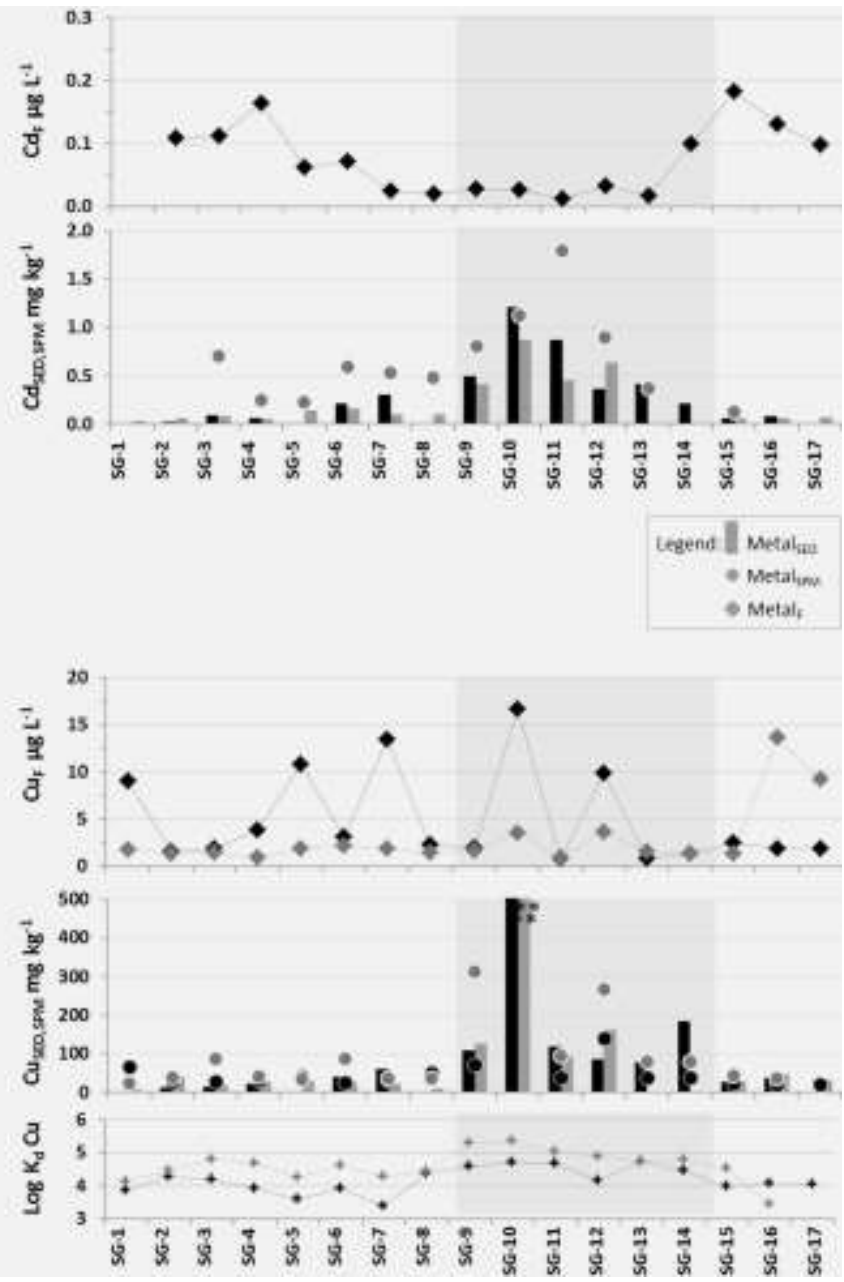

histograms and square represent $\mathrm{THg}$ and $\mathrm{MMHg}$ concentrations in sediment, respectively. The light gray area represents the urban zone. Asterisks highlight extreme values that could not be shown in the graph even with cut axis (refer to Supplementary dataset for values) 

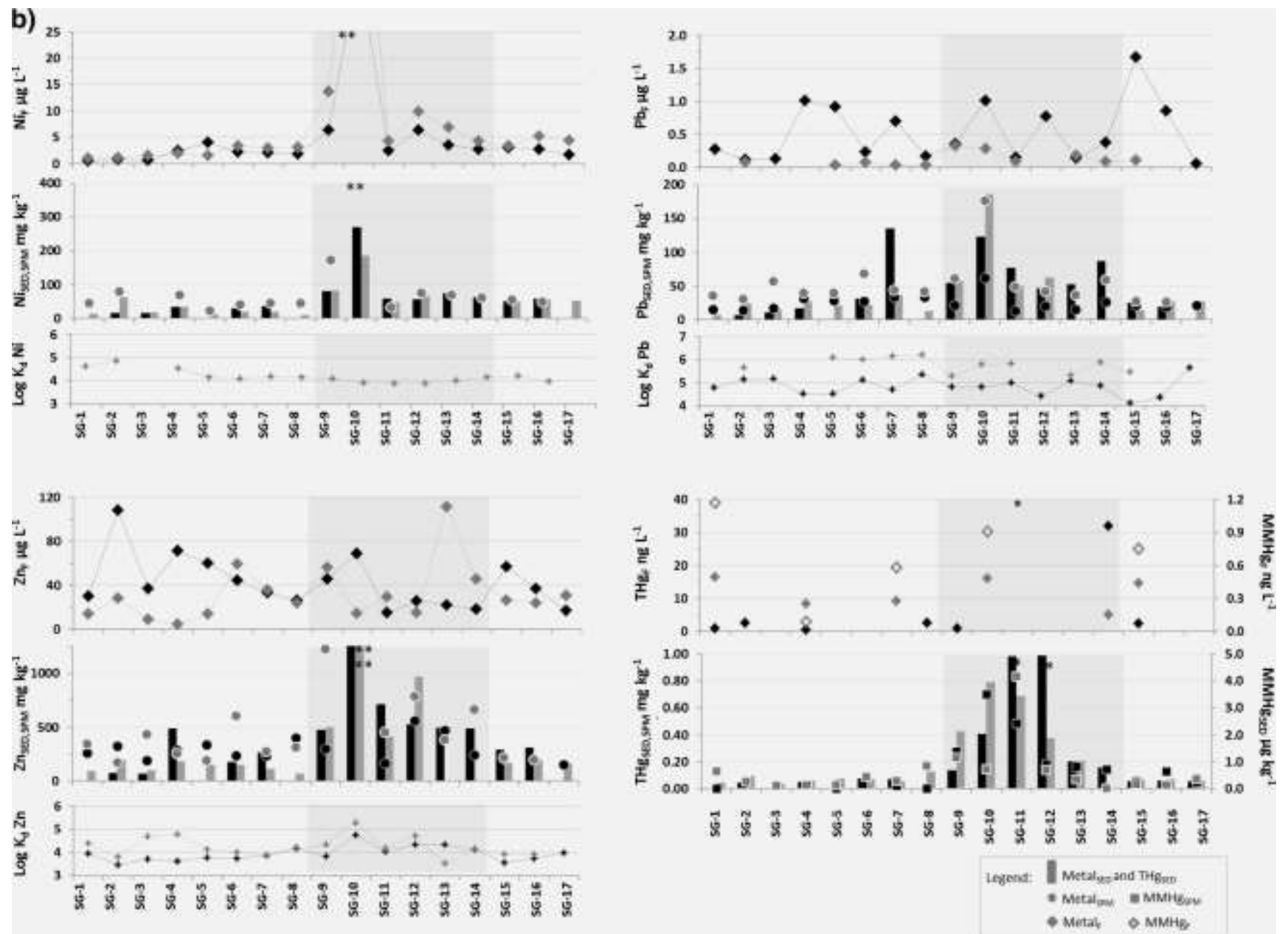

Fig. 4(continued)

measured in the smallest canals (i.e., Lo Gom canal (SG10) and Tham Luong canal (SG-12) while oxygen-depleted waters and lower nutrient concentrations are measured in the large Nhieu Loc Canal (SG-11) (Fig. 2; Supplementary data 1).This difference is likely due to the presence of wastewater interceptor installed during the last decade as part of a sanitation project (World Bank 2012) along the dense (1.2 million people) Nhieu Loc-Thi Nghe canal, allowing to centralize wastewater collection and avoiding direct wastewater release along the canal. In accordance, a transformational visual impact of the water quality was observed by local population (World Bank 2012; Givental 2014), pointing out the potential good resilience ability of the canal waters. Surprisingly, the Saigon River water quality in the center of HCMC (SG-14) is globally as good as the upstream river (SG-8) in terms of oxygenation levels, $\mathrm{pH}$, carbon, and nutrients (DOC, $\mathrm{POC}, \mathrm{N}-\mathrm{NO}_{3}, \mathrm{~N}-$ $\mathrm{NH}_{4}, \mathrm{P}-\mathrm{PO}_{4}$, and $\mathrm{TPP}$ ), suggesting an important dilution effect of the canal waters into the upstream river (Figs. 2 and $\underline{4 a}, \mathrm{~b}$; Supplementary data 1 and 2 ).

As for nutrients, filtered and particulate trace metal concentrations show a sharp rise in concentrations in the urban area (at least 2-fold higher-Fig. $\underline{4}$ a, b) due to water discharges from industrial and chemical plants of the urban area. The levels of concentrations are similar to measurements made in Hanoi urban waters and in the Red River watershed by Trinh et al. (2013). However, such concentrations remain under the level recommendations for drinking water (WHO 2011) and Vietnamese QCVN. Amongst metals, $\mathrm{Hg}$ and $\mathrm{MMHg}$ reached the highest value of the transect with values reaching 116 and $0.9 \mathrm{ng} \mathrm{l}^{-1}$ for $\mathrm{THg}_{\mathrm{F}}$ and $\mathrm{MMHg}_{\mathrm{F}}$, respectively, being 10 to 100 times the value measured in the upstream river. Such levels are in the range of reported concentrations in the waste water canals of Mexico City (Guédron et al. 2014a, b). In opposition to other metals, $\mathrm{Cd}_{\mathrm{F}}$ concentrations show a decrease in concentrations being close to worldwide riverine values (Viers et al. 2009), mirrored by the rise in $\mathrm{Cd}_{\mathrm{SED}}$ (Fig. 4a). This trend suggest that Cd solubility in this system is rather governed by total soluble sulfide reaction taking place at the oxic/anoxic interface and that sulfide precipitation reactions dominate over sulfide complexation reaction (Jacobs and Emerson 1982; Audry et al. 2006). In the HCMC's canal sediment, metal 
concentration remain similar for both seasons but showed a sharp rise with the pristine sediments being 2.5- to 9fold higher. AsSED, $\mathrm{Cr}_{\mathrm{SED}}, \mathrm{Pb}_{\mathrm{SED}}$, and $\mathrm{Zn}_{\mathrm{SED}}$ are in the range of concentration reported by other studies performed in HCMC canal sediments (Phuong et al. 2008; Huy et al. 2003; Anh et al. 2003; Thuy et al. 2007) whereas $\mathrm{Cd}_{\mathrm{SED}}, \mathrm{Cr}_{\mathrm{SED}}, \mathrm{Cu}_{\mathrm{SED}}, \mathrm{Ni}_{\mathrm{SED}}, \mathrm{Pb}_{\mathrm{SED}}$, and $\mathrm{Zn}_{\mathrm{SED}}$ are comparable with mean concentrations reported in urban sewer waters (Meybeck 2013) and $\mathrm{Hg}_{\text {SED }}$ are two to three times higher than Vientiane City's canals (Guédron et al. 2014a, b). Metal ${ }_{\text {SPM }}$ concentrations, measured for the first time in urban canals, vary with season: Metalspm are lower than Metal ${ }_{\mathrm{SED}}$ during the dry season and higher during rainy season (Fig. 4a), without showing a particular relation to oxygenation or SPM loads. This seasonal trend could be related to a change of partitioning between particulate and filtered phases due to change of $\mathrm{pH}$, DO, or salinity (e.g., ionic force (Turner 1996)) although no tendencies were evidenced between $\log K_{\mathrm{d}}{ }^{\mathrm{M}}$ and physicochemical parameters. It could also be related to enhanced particle remobilization during the rainy season although no daily water discharges and associated SPM fluxes data are measured in this system. Change of intensity of organ- ic matter degradation in the water column (Fig. $\underline{3}$ ) and/or to higher metal inputs via urban runoff during rainy sea- son could also explain the observed seasonal trend. Unfortunately, the snapshot campaigns conducted here is not sufficient to evaluate the predominance of the processes involved. As observed upstream, the low SPM concentrations in water induce an important dilution effect between Metal $_{\text {SPM }}$ expressed in milligrams per liter and Metal $_{\text {SED }}$. As for nutrients and physico-chemical parameters, high $\mathrm{Cr}_{\text {F-SED-SPM }}, \mathrm{Cu}_{\text {F-SED-SPM }}, \mathrm{Ni}_{\text {F-SED-SPM }}$, and $\mathrm{Hg}_{\text {F-SED-SPM }}$ and elevated $\mathrm{Zn}_{\mathrm{F} \text {-SED-SPM }}, \mathrm{Pb}_{\mathrm{F}-\mathrm{SED} \text {-SPM }}$, and $\mathrm{Cd}_{\text {SED-SPM }}$ concentrations (Supplementary data 2) were measured in anoxic waters of the smallest canals (Lo Gom canal SG-10) and Tham Luong canal (SG-12) likely due to reduction of redox sensitive elements and their carrier phases (e.g., Fe, Mn) while lower Metal F-SED-SPM $_{\text {ne }}$ were measured in oxygen-depleted waters of the large Nhieu Loc Canal (SG-11) (Supplementary data 2).

Finally, the Saigon River water quality in the center of HCMC (SG-14) remains globally as good as the upstream river (SG-8) regarding Metal $_{F}$ and Metalspm concentrations. Only Metal ${ }_{\mathrm{SED}}$ (especially $\mathrm{Cu}_{\mathrm{SED}}, \mathrm{Zn}_{\mathrm{SED}}, \mathrm{Hg}_{\mathrm{SED}}$, $\left.\mathrm{Pb}_{\mathrm{SED}}\right), \mathrm{Cd}_{\mathrm{F}}$, and $\mathrm{Hg}_{\mathrm{F}}$ concentrations present higher concentrations than in the upstream pristine area. Such feature likely illustrates the dilution of the urban water with fresh waters which dilute and favor metal precipitation.

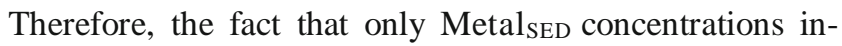
crease between SG-8 and SG-14 shows up that HCMC canal's water impact only the Saigon River's sediment and that sediment acts as a sink for metals.
Estuarine environment: dilution of urban water with marine waters

After the confluence with the Dong Nai River, the sampling sites SG-15 to SG-17 reflect a typical estuarine environment with the intrusion of marine waters characterized by increased conductivity, salinity, water oxygenation, and SPM concentrations, together with a grain size distribution dominated by silts (Fig. 2). Nutrients and organic carbon decrease drastically until reaching values as low as in the upstream area (Fig. 3). Dilution by seawater impoverished in nutrients could explain this trend for the filtered nutrients $\left(\mathrm{N}-\mathrm{NO}_{3}, \mathrm{~N}-\mathrm{NH}_{4}\right.$, and $\left.\mathrm{P}-\mathrm{PO}_{4}\right)$. Additional processes such as $\mathrm{P}$ desorption from SPM or organic matter degradation can explain the decrease of organic carbon and particulate P content of SPM (Némery and Garnier 2007). Such well-documented dilution effect along the salinity gradient (Garnier et al. 2010) is well illustrated by nutrient concentrations decrease which drops in concentration of 2- to 9fold in comparison with those of the urban area. Similarly, levels of Metal $($ except AsP) drop to reach levels slightly higher than the upstream pristine area with similar concentrations between suspended and deposited sediments for both seasons. Despite the few number of samples taken in the salinity gradient, $\mathrm{Cd}_{\mathrm{F}}, \mathrm{Cr}_{\mathrm{F}}$, and $\mathrm{Pb}_{\mathrm{F}}$ express an additive behavior (e.g., a non-conservative mixing between the riverine and oceanic end-embers resulting in higher concentrations than expected by the conservative mixing (Boyle et al.1974) (Fig. $\underline{5}$ ). This feature, well documented for $\mathrm{Cd}_{\mathrm{F}}$ as a chloride-induced desorption/complexation processes (e.g., Comans and van Dijk 1988; Dabrin et al. 2009), is rare for $\mathrm{Pb}_{\mathrm{F}}$ and $\mathrm{Cr}_{\mathrm{F}}$, which rather exhibit scavenging onto particles (e.g., Chiffoleau et al. 1994; Campbell and Yeats 1984). $\mathrm{As}_{\mathrm{F}}, \mathrm{Cu}_{\mathrm{F}}, \mathrm{Ni}_{\mathrm{F}}, \mathrm{Zn}_{\mathrm{F}}$, and $\mathrm{Hg}_{\mathrm{F}}$ variations do not exhibit specific behavior despite local $\mathrm{Metal}_{\mathrm{F}}$ shift. Further sampling along the salinity gradient is required to characterize the processes controlling their filtered/particulate distributions.

\section{Polymetall(oid)ic contamination assessment of the Saigon River}

In order to facilitate the comparison of the Metal ${ }^{\mathrm{P}}$ SED variations along the river, EF have been determined, using the site SG-3 Ben Cui as natural background (see BEnrichment factor $\wedge)$. The $\mathrm{EF}$ evidence minor $(\mathrm{Cr}-\mathrm{Hg}-$ $\mathrm{Zn}-\mathrm{Cd}-\mathrm{Pb}$ ) to moderate enrichments $(\mathrm{As}-\mathrm{Cu})$ of the river' sediments in- and downstream HCMC, and severe to extremely severe enrichments for all metals in the sediments from the canals (Fig. 6).Compared with tropical environments, the EF enrichment of the Saigon River sediment are much higher than in larger system as the lower Ganges-Brahmaputra-Meghna River system $\left(200,000 \mathrm{~km}^{2}\right.$ 

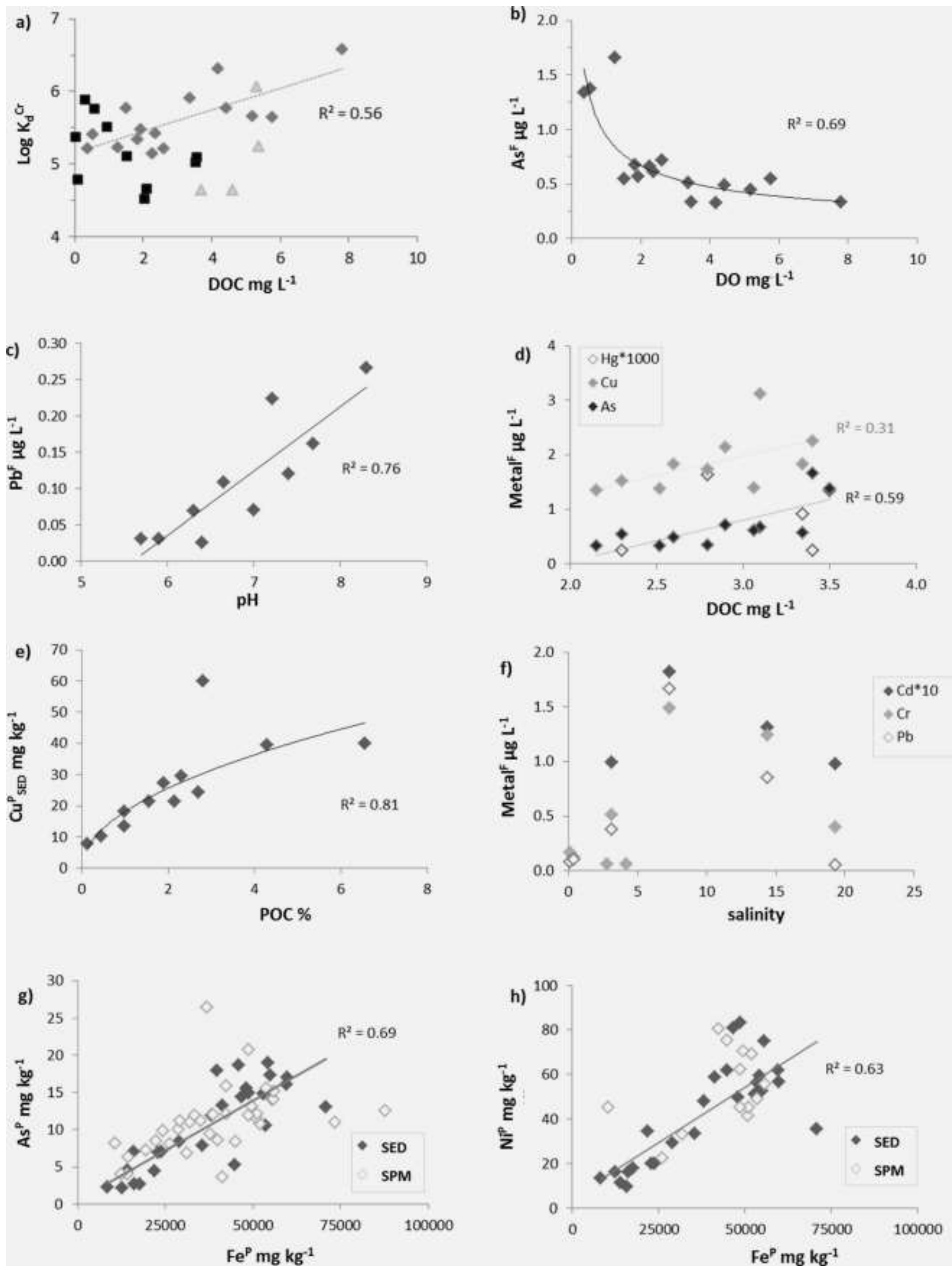
Fig. 5 Relationship between metal concentrations and physico-chemical parameters: $\operatorname{a} \log K_{\mathrm{d}}$ and DOC from the three zones and during both seasons; $\mathrm{b} \mathrm{As} F$ and $\mathrm{DO}$ from upstream and during both seasons; $\mathrm{c} \mathrm{Pb}_{\mathrm{F}}$ and $\mathrm{pH}$ from upstream and during both seasons; $\mathrm{d} \mathrm{Hg}_{\mathrm{F}}, \mathrm{As}_{\mathrm{F}}, \mathrm{Cu}_{\mathrm{F}}$, and DOC

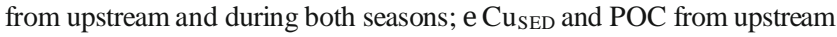

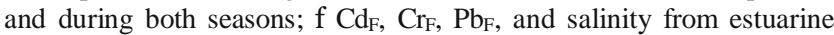
environment area and during both seasons; g As SPM,SED $_{\text {and Fe }}$ Fe $_{S P M}$,SED from the entire basin and during both seasons; $\mathrm{h} \mathrm{Ni}_{\text {SPM,SED }}$ and Fe SPM,SED from the entire basin and during both seasons

with high population density; Datta and Subramanian $\underline{1998)}$ but in the same range than rivers with similar drainage area and population density like the Chao Phraya River in Thailand (Wijaya et al. 2013) or the Korotoa River in Bangladesh (Islam et al. 2015). Interestingly, the urban Seine River characterized by a similar popula- tion growth, river size, and low SPM transport showed actual EF in the same range as the Saigon River (except the more contaminated urban canals) but past EF (1960s and 1970s) much more higher (Meybeck et al. 2007). Such differences may be mainly attributed to the drainage areas of rivers but also to their historical past, the European Rivers as the Seine River being historically more impacted by heavy industries, smelting and/or min- ing activities than the Southern Asian Rivers. To summa- rize, the megacity HCMC has a moderate chemical impact on the Saigon River but the factors controlling its extent (e.g., inherent physical and environmental features) are still under-estimated. In fact, the Saigon River does not

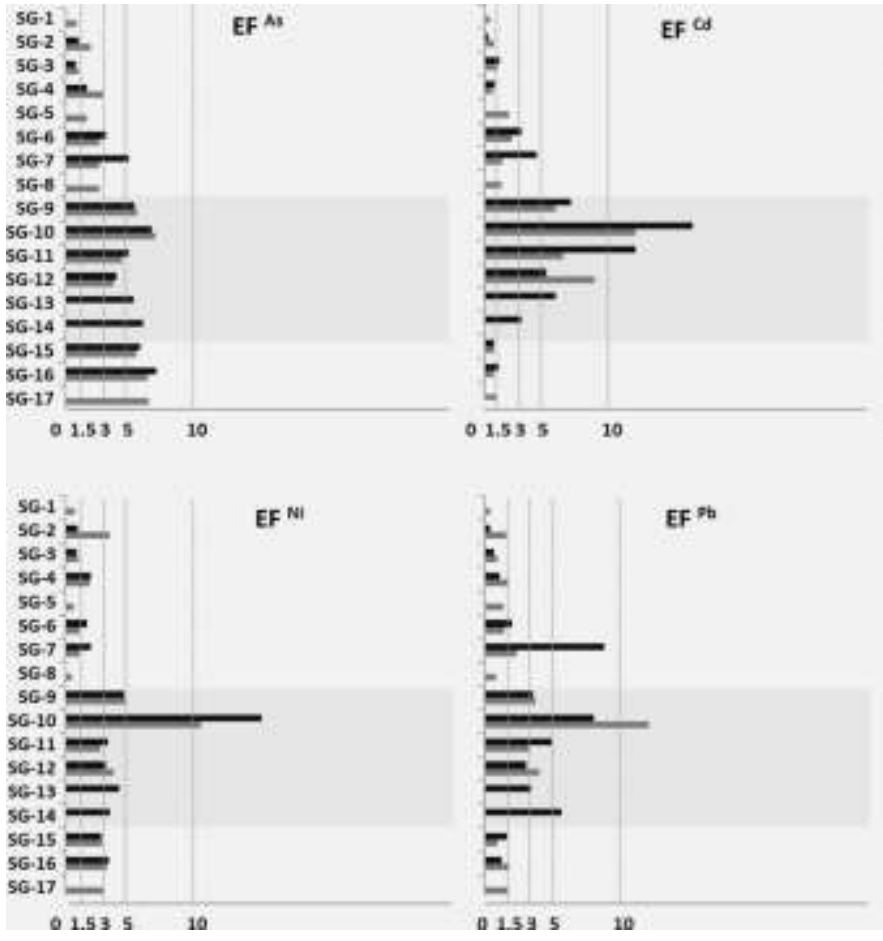

Fig. 6 Metal $_{\mathrm{SED}}$ enrichment factor determined in the 17 sampling sites during dry (black) and rainy (gray) seasons. The light gray area represents the urban zone. $\mathrm{EF}<1.5$ : natural weathering processes; present the typical dilution effect during the wet season observed in most tropical rivers (Chanpiwat and Sthiannopkao, 2013). This limited dilution effect attributed by Chanpiwat and Sthiannopkao (2013) to the short period of Vietnam's rainfall and to the flow recharge from the Saigon River to the various aquifers, might also be due to the water flow regulation from the Dau Tieng reservoir, the confluence with the Dong Nai River, and the tidal marine water intrusion (up to HCMC). These features should be considered in further studies.

\section{Conclusions}

The Saigon River is a contrasted system in terms of geochemistry (e.g., salinity, pH, etc.) and human activities, e.g., agriculture (rubber, vegetables, paddy rice), industry, urban activities, harbor, maritime activity, and intensive aquaculture. Our study showed that untreated wastewaters combined with industrial discharges conduct to the degradation of canals and Saigon River's water quality. Considering the entire set of studied metals, we can conclude that the Saigon River remains moderately contaminated albeit the city was proved to be the major contributor of metal(oid)s. We also highlighted that metal(oid) inputs and partitioning in water along the Saigon River is driven by both natural and anthropogenic factors such as $\mathrm{pH}, \mathrm{DO}$, ionic strength, and organic matter. Furthermore,
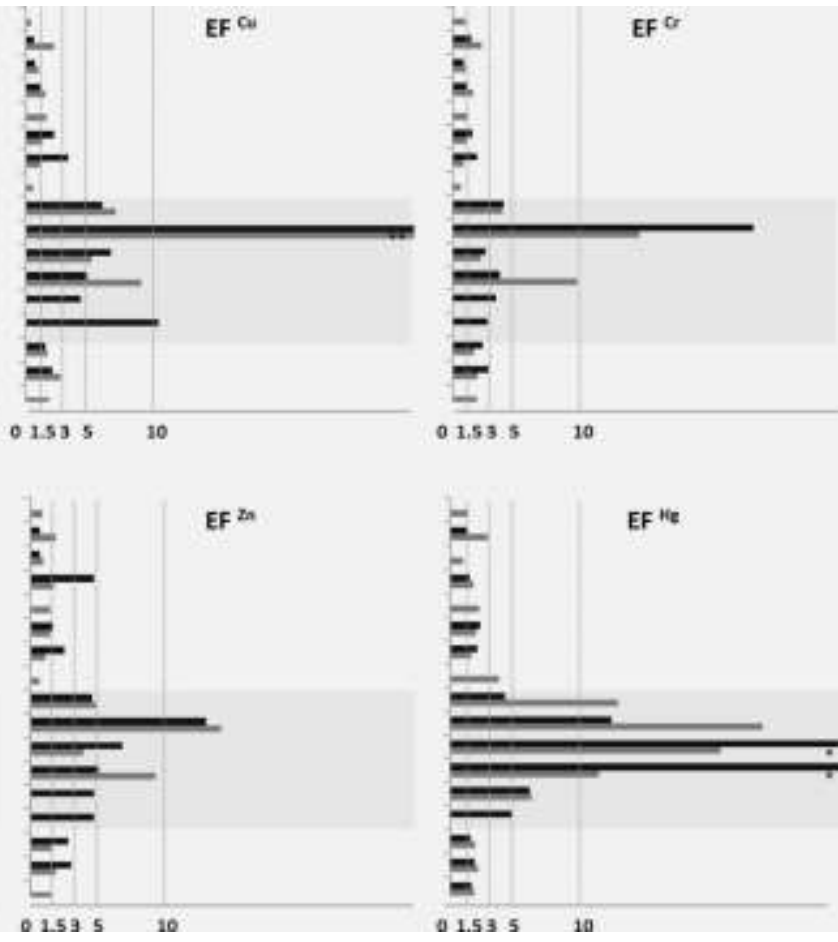

$1.5<\mathrm{EF}<3$ : minor anthropogenic enrichment; $3<\mathrm{EF}<5$ : moderate anthropogenic enrichment; $5<\mathrm{EF}<10$ : moderate severe anthropogenic enrichment; $10<\mathrm{EF}<50$ : extreme severe anthropogenic enrichment 
oxygen depletion in the river is obviously due to intense bacterial consumption of oxygen through both nitrification and heterotrophic degradation. The fate of nutrients, organic carbon, and metals in tropical estuaries receiving high level of urban waste water inputs from Megacity has to be better understood to evaluate the potential eutrophication of coastal areas, the metal and $\mathrm{C}, \mathrm{N}$, and $\mathrm{P}$ loads to coastal zone and sensitive environment such as mangroves and the metal transfer through aquatic food chain. Amongst metals, although $\mathrm{Hg}$ and MMHg data are scarce and exploratory (only measured during the wet season), the high levels of $\mathrm{MMHg}_{\mathrm{F}}$ are a concern and further investigations are needed to focus on the determination methylation process involved and more specifically on the accumulation of both metal and $\mathrm{MMHg}$ in fish which may be a major concern for riverine population whose diet rely on fish consumption. The recent and rapid demographic and industrial development of the economic capital HCMC is one of the most important challenges that policy makers and water managers will have to deal with within the next decade, especially in a context of climate change (e.g., rising sea levels, flooding, erosion, seawater intrusion). In the future, the resiliency of the system, strongly linked to domestic and industrial wastewater improvement, should be considered to evaluate the impact of HCMC through the water quality of the Saigon River.

Acknowledgments This study has been conducted under the framework of CARE-RESCIF initiative. The authors would like to thank the students for their help during sampling. This study was funded by incentive grants from Institut de Recherche pour le Développement IRD, by AGIR grants from Grenoble Alpes University, by grants from the Vietnam National University (grant number B2016-20-05), and by grants from Region Rhônes Alpes COOPERA BTake Care.^ LTHE is part of Labex OSUG@2020 (ANR10 LABX56).

\section{References}

Aminot A and Kerouel R (2004). Hydrologie des écosystèmes marins. Paramètres et analyses. Edition Ifremer.

Anh MB, Hong LCD, Nguyen NV, Thi CLT, Minh TL, Becker-Van Slooten K, Tarradellas J (2003) Micropollutants in the sediment of the SaiGon-DongNai River: situation and ecological risks. Chimia 57:537-541

APHA 1995. Standard Methods for the Examination of Water and Wastewater, American Public Health Association. Washington, DC

Apitz SE, Power EA (2002) From risk assessment to sediment management: an international perspective. J. Soils Sediments 2:61-66

Aspila KI, Agemian H, Chau ASY (1976) A semi-automated method for the determination of inorganic, organic and total phosphate in sediments. Analyst 10:1187-1197

Audry S, Blanc G, Schäfer J, Chaillou G, Robert S (2006) Early diagenesis of trace metals $(\mathrm{Cd}, \mathrm{Cu}, \mathrm{Co}, \mathrm{Ni}, \mathrm{U}, \mathrm{Mo}$, and $\mathrm{V})$ in the freshwater reaches of a macrotidal estuary. Geochim Cosmochim Acta 70: 2264-2282

Balogh SJ, Nollet YH (2008) Methylmercury input to the Mississippi River from a large metropolitan wastewater treatment plant. Sci Tot Environ 406:145-153
Balogh SJ, Swain EB, Nollet YH (2006) Elevated methylmercury concentrations and loadings during flooding in Minnesota rivers. Sci Tot Environ 368:138-148

Benoit JM, Gilmour C, Mason R, Heyes A (1999) Sulfide controls on mercury speciation and bioavailability to methylating bacteria in sediment pore waters. Environ Sci Technol 33:951-957

Benoit JM, Gilour CC, Heyes A, Mason RP, Miller CL (2003) Geochemical and biological controls over methylmercury production and degradation in aquatic ecosystems. In: Cai Y, Braids OC (eds) Biochemistry of environmentally important trace elements. ACS symposium series 835. American Chemical Society, Washington, DC, pp. 262-297

Berg M, Trang PTK, Stengel C, Buschmann J, Viet PH, Dan VN, Giger W, Stüben D (2008) Hydrological and sedimentary controls leading to arsenic contamination of groundwater in the Hanoi area, Vietnam: the impact of iron-arsenic ratios, peat, river bank deposits, and excessive groundwater abstraction. Chem Geol 249:91-112

Bloom NS, Fitzgerald WF (1988) Determination of volatile mercury species at the picogram level by low-temperature gas chromatography with cold-vapor atomic fluorescence detection. Anal Chim Acta 208:151-161

Boyle E, Collier R, Dengler AT, Edmond JM, Ng AC, Stallard RF (1974) On the chemical mass-balance in estuaries. Geochim Cosmochim Acta 38:1719-1728

Bravo AG, Bouchet S, Guédron S, Amouroux D, Dominik J, Zopfi J (2015) High methylmercury production under iron-reducing conditions in sediments impacted by sewage treatment plant discharges. Wat Res 80:245-2552015

Campbell JA, Yeats PA (1984) Dissolved chromium in the St. Lawrence estuary. Estuar Coast Shelf S 19:513-522

Castelle S, Schafer J, Blanc G, Audry S, Etcheber H, Lissalde JP (2007) 50-year record and solid state speciation of mercury in natural and contaminated reservoir sediment. Appl Geochem 22:1359-1370

Censi RM, Martin JM (2004) Concentration and fate of trace metals in Mekong River Delta. Sc Tot Environ 332:167-182

Chanpiwat P, Sthiannopkao S (2013) Status of metal levels and their potential sources of contamination in southeast Asian rivers. Environ Sci Pollut Res. doi:10.1007/s11356-013-1858-8

Chiffoleau JF, Cossa D, Auger D, Truquet I (1994) Trace metal distribution, partition and fluxes in the seine estuary (France) in low discharge regime Spatio. Mar Chem 47:145-158

Comans RNJ, van Dijk CPJ (1988) Role of complexation processes in cadmium mobilization during estuarine mixing. Nature 336:151154

Conley DJ, Paerl HW, Howarth RW, Boesch DF, Seitzinger SP, Havens KE, Lancelot C, Likens GE (2009) Controlling eutrophication: nitrogen and phosphorus. Science 323:1014-1015

Cossa D, Gobeil C (2000) Mercury speciation in the lower St. Lawrence estuary. Can J Fish Aquat Sci 57:138-147

Cossa D, Mason RP, Fitzgerald WF (2006) Chemical speciation of mercury in a Meromictic lake. In: WC J, HJ W (eds) Mercury pollution: integration and synthesis. CRC Press, Inc., pp. 57-67

Coulthart A, Quang N, Sharpe H (2006) Urban development strategy. Meeting the challenges of rapid urbanization and the transition to a market oriented economy (Monograph). World Bank, Hanoi, Vietnam

Dabrin A, Schäfer J, Blanc G, Strady E, Masson M, Bossy C, Castelle S, Girardot N, Coynel A (2009) Improving estuarine net flux estimates for dissolved cadmium export at the annual timescale: application to the Gironde estuary. Estuar Coast Shelf S 84:429-439

Dan NP, Ha NTV, Thanh BX, Khoa HL (2007). Water resources management in Ho Chi Minh City. Institute for Global Environmental Strategies IGES report, Kanagawa, Japan. http://pub.iges.or. $\mathrm{jp} /$ modules/envirolib/upload/981/attach/00_complete report.pdf 
Datta DK, Subramanian V (1998) Distribution and fractionation of heavy metals in the surface sediments of the Ganges-Brahmaputra-Meghna river system in the Bengal basin. Environ Geol 36:93-101

Etcheber H, Relexans JC, Beliard M, Weber O, Buscail R, Heussner S (1999) Distribution and quality of sedimentary organic matter on the Aquitanian margin (Bay of Biscay). Deep-Sea Res Part II 46:2249_ 2288

Evans AEV, Hanjra MA, Jiang Y, Qadir M, Drechsel P (2012) Water quality: assessment of the current situation in Asia. Int $\mathrm{J}$ WaterResour Dev 28:195-216

Food and Agricultural Organization (FAO) (2014). Aquastat: Global information system on water and agriculture. http://www.fao. org/nr/water/aquastat/data/cf/readPdf.html?f=VNM-CF_eng.pdf

Förstner U, Salomons W (2008) Trends and challenges in sediment research: the role of sediments in river basin management. J Soils Sed 8:281-283

Gaillardet J, Dupré B, Allegre CJ (1999) Geochemistry of large river suspended sediments: silicate weathering or crustal recycling? Geochim Cosmochim Acta 63:4037-4051

Garnier J, Billen G, Cébron A (2007) Modelling nitrogen transformations in the lower Seine river and estuary (France): impact of wastewater release on oxygenation and N2O emission. Hydrobiol 588:291-302

Garnier J, Billen G, Némery J, Sebilo M (2010) Transformations of nutrients $(\mathrm{N}, \mathrm{P}, \mathrm{Si})$ in the turbidity maximum zone of the Seine estuary and export to the sea. Est Coast Shelf Sc 90:129-141

General Statistics Office of Vietnam (GSO) (2014). Statistical yearbook of Ho Chi Minh City-2013, Ho Chi Minh City Statistical Office.

Givental E (2014) The Ho Chi Minh City canals: assessing vulnerability and resilience factors. Association of Pacific Coast Geographers Yearbook 76:49-67

Guédron S, Duwig C, Prado BL, Point D, Flores MG, Siebe C (2014a) (Methyl)mercury, arsenic, and lead contamination of the World's largest wastewater irrigation system: the Mezquital Valley (Hidalgo State-Mexico). Water Air Soil Poll 225:-2045

Guédron S, Grangeon S, Lanson B, Grimaldi M (2009) Mercury speciation in a tropical soil association; consequence of gold mining on $\mathrm{Hg}$ distribution in French Guiana. Geoderma 153:331-346

Guédron S, Tisserand D, Garambois S, Spadini L, Molton F, Bounvilay B (2014b) Baseline investigation of (methyl)mercury in waters, soils, sediments and key foodstuffs in the lower Mekong Basin: the rapidly developing city of Vientiane (Lao PDR). J Geochem Explor 143:96-102

Huy NQ, Luyen TV, Phe TM, Mai NV (2003) Toxic elements and heavy metals in sediments in Tham Luong Canal, Ho Chi Minh City, Vietnam. Environ Geol 43:836-841

Islam MS, Ahmed MK, Raknuzzaman M, Al-Mamun MH, Islam MK (2015) Heavy metal pollution in surface water and sediment: a preliminary assessment of an urban river in a developing country. Ecol Indicat 48:282-291

Jacobs L, Emerson S (1982) Trace metal solubility in an anoxic fjord. Earth Planet Sci Let 60:237-252

Jeffrey SW (1980) Algal pigment systems. In: Falkowski PG (ed) Primary productivity in the sea. Plenum, New York, pp. 33-58

Lohring DH (1991) Normalization of heavy-metal data from estuarine and coastal sediments. ICES J Mar Sc 48:101-115

Luu TNM, Garnier J, Billen G, Le TPQ, Nemery J, Orange D, Le LA (2010) N, P, Si budgets for the Red River Delta (northern Vietnam): how the delta affects river nutrient delivery to the sea. Biogeochem 107:241-259

Marcotullio PJ (2007) Urban water-related environment transitions in Southeast Asia. Sustain Sci 2:27-54

Meybeck M (2013) Heavy metal contamination in rivers across the globe: an indicator of complex interactions between societies and catchments. In: Proceeding of H04, IAHS-IAPSO-IASPEI Assembly, Gothenburg, Sweden, 2013.
Meybeck M, Lestel L, Bonte P, Moilleron R, Colin J, Rousselot O, Herve D, De Ponteves C, Groisbois C, Thevenot D (2007) Historical perspectives of heavy metal contamination $(\mathrm{Cd}, \mathrm{Cr}, \mathrm{Cu}, \mathrm{Hg}, \mathrm{Pb}, \mathrm{Zn})$ in the seine river basin (France) following a DPSIR approach (19502005). Sci Total Environ 375:204-231

Meybeck M, Roussenac S, Dürr H, Vogler J (2005) Lateral carbon transport in freshwaters. CarboEurope Cluster report, $55 \mathrm{p}$.

Minh NH, Minh TB, Iwata H, Kajiwara N, Kunisue T, Takahashi S, Viet PH, Tuyen BC, Tanabe S (2007) Persistent organic pollutants in sediments from Sai Gon-Dong Nai River basin, Vietnam: levels and temporal trends. Arch Environ Contam Toxicol 52:458-465

Murphy J, Riley JP (1962) A modified single solution method for the determination of phosphate in natural waters. Anal Chimica Acta 27:31-36

Némery J, Garnier J (2007) Origin and fate of phosphorus in the seine watershed (France): the agricultural and hydrographic P budget. J Geo Res Biogeosci 112

Nguyen TVH, Takizawa S, Oguma K, Nguyen VP (2011) Sources and leaching of manganese and iron in the Saigon River Basin, Vietnam. Water Sc Techno 63:2231-2237

Parker JL, Bloom NS (2005) Preservation and storage techniques for lowlevel aqueous mercury speciation. Sc Total Environ 337:253-263

Patterson CC, Settle DM (1976) The reduction of orders of magnitude errors in lead analyses of biological materials and natural waters by evaluating and controlling the extent and sources of industrial lead contamination introduced during sample collecting, handling, and analysis. Natl Bureau Stand Special Publ 422:321-351

Phuong PK, Son CPN, Sauvain JJ, Tarradellas J (2008) Contamination by PCB's, DDT's, and heavy metals in sediments of Ho Chi Minh City's canals, Viet Nam. Bull Environ Contam Toxicol 60:347-354 QCVN

(2008) QCVN 08:2008/BTNMT, National Technical Regulation on Surface Water Quality, Hanoi, Vietnam.

Rang MC, Kleijn CE, Schouten CJ (1986) Historical changes in the enrichment of fluvial deposits with heavy metals. Int Assoc Hydrol Sci Publ 157:47-59

Sajor EE, Thu NM (2009) Institutional and development issues in integrated water resource management of Saigon River. J Envir Devel 1: 268-290

Sonke JE, Schäfer J, Chmeleff J, Audry S, Blanc G, Dupré B (2010) Sedimentary mercury stable isotope records of atmospheric and riverine pollution from two major European heavy metal refineries. Chem Geol 279:90-100

Sugimura Y, Suzuki Y (1988) A high temperature catalytic oxidation method for non-volatile dissolved organic carbon in seawater by direct injection of a liquid sample. Mar Chem 24:105-131

Svendsen LM, Redsdorf A, Nørnberg P (1993) Comparison of methods for analysis of organic and inorganic phosphorus in river sediment. Water Res 27:77-83

Thuy HTT, Nguyen NHV, Tu TCL (2007) Anthropogenic input of selected heavy metals $(\mathrm{Cu}, \mathrm{Cr}, \mathrm{Pb}, \mathrm{Zn}$ and $\mathrm{Cd})$ in the aquatic sediments of Hochiminh City, Vietnam. Water Air Soil Poll 182:73-81

Trinh AD, Giang NH, Vachaud G, Choi SU (2009) Application of excess carbon dioxide partial pressure $\left(\mathrm{EpCO}_{2}\right)$ to the assessment of trophic state of surface water in the Red River Delta of Vietnam. Int J Environ Stud 66:27-47

Trinh AD, Meysman F, Rochelle-Newall E, Bonnet MP (2012) Quantification of sediment-water interactions in a polluted tropical river through biogeochemical modeling. Glob Biogeochem Cycles 26:GB3010. doi:10.1029/2010GB003963

Trinh AD, Vu DL, Ta TT (2013) Partition of heavy metals in a tropical river system impacted by municipal waste. Environ Monit Assess 185:1907-1925

Turner A (1996) Trace-metal partitioning in estuaries: importance of salinity and particle concentration. Mar Chem 54:27-39 
Turner A, Millward GE, Bale AJ, Morris AW (1993) Application of the $\mathrm{K}_{\mathrm{D}}$ concept to the study of trace metal removal and desorption during estuarine mixing. Estuar Coast Shelf S 36:1-13

Turner DR, Whitfield M, Dickson AG (1981) The equilibrium speciation of dissolved components in freshwater and seawater at $25^{\circ} \mathrm{C}$ and 1 atm pressure. Geochim Cosmochim Acta 45:855-881

van Leeuwen CJ, Nguyen PD, Dieperink C (2015) The challenges of water governance in Ho Chi Minh City. SETAC 2015. Integr Environ Assess Manag 9999:1-8

Viers J, Dupré B, Gaillardet J (2009) Chemical composition of suspended sediments in world rivers: new insights from a new database. Sci Total Envir 407:853-868

Vo PL (2007) Urbanization and water management in Ho Chi Minh City, Vietnam-issues, challenges and perspectives. GeoJ 70:75-89

Wedepohl H (1995) The composition of the continental crust. Geochim Cosmochim Ac 59:1217-1232
Wetzel RG (1983) Limnology, 2nd edn. Saunders College Publishing, Philadelphia, $860 \mathrm{pp}$

WHO (2011) Guidelines for drinking-water quality, fourth Eds, 564p. Organization, World Health

Wijaya AR, Ouchi AK, Tanaka K, Cohen MD, Sirirattanachai S, Shinjo $\mathrm{R}$, Ohde $\mathrm{S}$ (2013) Evaluation of heavy metal contents and Pb isotopic compositions in the Chao Phraya River sediments: implication for anthropogenic inputs from urbanized areas, Bangkok. J Geoch Explor 126-127:45-54

World Bank (2012). Vietnam-Ho Chi Minh City Environmental Sanitation (Nhieu Loc-Thi Nghe Basin) Project.Washington,DC: WorldBank.http://documents.worldbank.org/curated/en/2012/12 /17151849/vietnam-ho-chi-minh-city-environmental-sanitationnhieu-loc-thi-nghe-basin-project

Zhang J, Liu CL (2002) Riverine composition and estuarine geochemistry of particulate metals in China: weathering features, anthropogenic impact and chemical fluxes. Estuar Coast Shelf S 54:1051-1070 